\title{
The grammar of graves
}

\section{Introduction: \\ mortuary grammar and community identity}

Cemeteries were spaces in which to dispose of the dead, to remove social and physical pollution by partitioning the dangerous decomposing body away from living space; and so prevent exposure to noxious odours. But disposal alone is too simplistic and perfunctory to explain the role of a burial ground because cemetery spaces hosted funerals, which were temporal events that recreated social bonds, allowing them to be forged anew following loss (Metcalf and Huntington, 1991). As a consequence, cemeteries were places for living people and communities, and it was these communities who adopted the material, visual and linguistic means to describe their deceased and in doing so they described themselves as well (Williams and Sayer, 2009). Cemeteries were social apparatus, resources which could be employed in the construction and maintenance of living and evolving identities. Part of this expression described the dead's relationships to the living funeral goers using shared processes: memory, performance, language and physical knowledge, such as material culture, aesthetic and space. The dead were placed in a grave using a communication that described their relationship to others among the funeral party, within the cemetery and among the wider world. The dead did not lie down to die in the grave, but their affiliations were captured in a mortuary culture that resulted from multiple agents engaged in internalised and articulated negotiations which included emotional, familial, community, political and economic changes.

Social identity is not a simple phenomenon, but the result of a nexus of nested and competing concerns. Which aspects of identity are externally expressed and to whom they are expressed all depend on an individual's circumstances, both immediate and personal (Sayer, 2010). The way an individual behaves will be different in the presence of a war band, a family or a religious community, and is dependent on that person's political affiliation and belief system, as well as age and gender 
among other things. But identity is as much a set of different cultural constructions as it is an ongoing, evolving process changing over a life's course, as circumstance and relationships themselves change. This persona depends on participants who make sense of the world around them though a matrix of semiotics expressed as conceptual, material and physical cultures consumed within social life and through communication. The result is a way of perceiving difference and creating similarities that identify, define or create networks between people and communities, but also utilises material things, visual processes and language in the expression of those relationships. In short, people use a combination of mythology, material culture and speech to construct coherent individual and group identities that provide a way to understand and structure their association with others.

The negotiations embedded in early Anglo-Saxon mortuary behaviour employed a mixture of semiotics expressed through a combination of spoken and visual knowledge. Some of these visual tools survive in the archaeological record and are described in Chapter 2, and they included grave clusters, grave orientation, grave density and choice of burial rite, where relational situations were articulated though the juxtaposition of similarity and difference. Other expressive technologies were part of individual funerary display and these included grave location, gravegoods, body positions or proximity to barrows, or other features that were embedded in cemetery architecture. In combination, these things provided ways for funeral celebrants to express and recognise their association with the deceased and other participants, and it is because this message was meant to be understood, even physical and verbally articulated, that we can discover it.

Mortuary variation is not a mirror of living society (Williams and Sayer, 2009; Chapman et al., 1981; Parker Pearson, 1999: 73). Gravegoods were deliberately used to dress a corpse or placed into a grave, and so they may convey specific and meaningful messages to different groups of people. The nature of the message is entangled within their relationships; however, some of these messages can be explored. Furnished graves often included sets of objects: a furnished male burial is one with a weapon set, a shield and spear; a woman's burial is furnished with a pair of brooches (Härke, 1994; Stoodley, 1999). These material characteristics carried important visual messages at specific times: for example, a combination of high-resolution radiocarbon dates and Bayesian statistics reveals that furnished burials of these types were most popular in the mid-sixth century (Hines and Bayliss, 2013). As a result, gravegoods and gravegood combinations are important ways to study a site, but they may be misleading if relied upon to the exclusion of other evidence. The implication of Hines and Bayliss' discovery is that a 
person of high social rank may be buried with limited or no gravegoods in the early and the late-sixth century. Nonetheless, the cemetery space was a tool to structure narrative portrayals of the past, and so this chapter explores the methods that were employed to organise grave plots, to create central places or to mark out people and relationships. This chapter looks at the internal organisation of early Anglo-Saxon cemeteries by exploring how burial wealth, gender, sex and age were expressed at the point of burial. It will also examine the afterlife of a grave, looking at subsequent burial locations and grave robbing, because all of these leitmotifs are an expression of personality and intercommunity relationships.

\section{Social status, wealth and core burials}

Social status is, quite rightly, a problematic term and a contentious issue, but the presence of social rank in past societies, and particularly the Early Middle Ages, is not an issue of dispute; it is how archaeologists investigate it that is problematic. Previous scholars have relied on the presence or absence of gravegoods to investigate the social elite (Parker Pearson, 1999: 78). Among Anglo-Saxon archaeologists, these investigations have often focused on the quantity or quality of material in the graves, or relied on a knowledge of the character of specific objects to make conjectures (Arnold, 1981). The principle behind these investigations was the assumption that in a stratified society the elite displayed their status in the grave. This is viewed as a form of competitive consumption used to signal their identity or rank in a way that allowed the surviving family, or remaining elite, to legitimate their own position within the community (Parker Pearson, 1982; 1984; Morris, 1991).

Burial display is not simply focused on wealth, and Arthur Saxe (1970) suggested that the number and range of gravegoods may relate to the role of the deceased in society, and how many people attended a funeral. For example, a single adult male may have had nothing, or simply a knife, but a married adult male was also a husband and so his wife may have placed additional objects in the grave. The greater an individual's investment in society, Saxe speculated, the more people had a connection with them and so many more people would have contributed to the funeral or placed objects in the grave. In Saxe's model a father or mother, a general, king or religious leader would have people from each social role attending and contributing to their funeral. Thus the more of these categories they belonged to, the more people from each group attended - for example, children, subjects, soldiers or congregations. As a result the funeral event signalled their importance and allowed a 
broader range of people to renew their social bonds in that person's absence. Consequently, wealth positioned in the grave may have been placed there directly, or indirectly, by funeral participants, or because the surviving funeral organisers created an opportunity to show off their own importance and wealth at a local, regional or national scale. This is an important concept because it connects the objects found in a grave with the community who placed them there. However, this concept also highlights one of the key problems: members of the funeral party selected how the dead were dressed, with what they were accompanied, who attended a funeral and how the commemoration was structured. This means that an individual was prepared, presented, buried and commemorated in a way meaningful to the funerary party and relevant at a specific point in time and for a particular generation or group of people.

The presence of gravegoods in early medieval cemeteries has a long tradition of being associated with rank; for example, Heiko Steuer (1968) analysed Frankish and Alemannic cemeteries and connected wealthy individuals with an elite defined in the Merovingian legal codes. This system influenced C. J. Arnold (1981), who similarly identified ranks defined in the Anglo-Saxon legal codes within Bernicia's cemeteries (although no codes survive from this kingdom). Christlein (1973) and Shephard (1979) both proposed comparable systems of qualitative investigation, suggesting three or five social ranks identifiable from the gravegoods (see Table 4.1). These systems are based around a tripartite ranking scheme - with the absence of gravegoods, or the presence of just basic equipment such as a knife, bead or single buckle, being at the lowest rank, an average set of equipment in the middle rank or ranks, and exceptional equipment including gold, silver or equine equipment at the top. Shephard subdivided the bottom rank into two, those with and without gravegoods. However, the fact that organic material such as soft furnishings, clothing, filleted meat and wooden objects would not survive for the archaeologist means that these categories are largely artificial. Shephard also subdivided the middle rank into two, separating men with a single weapon and women with a single brooch from those with a full, if not spectacular, set of equipment, usually defined as a two-weapon combination, or a pair of brooches and a set of beads (see Chapter 1).

These studies are problematic, firstly because they do not address regional or chronological variants. For example, graves in Kent are significantly wealthier on average than the graves found in West Sussex or the Thames Valley. At Deal, Kent, for example, the majority of burials, some 53 per cent (of seventy-six inhumations) would fit into Shephard's $\mathrm{A}, \mathrm{B}$ or $\mathrm{C}$ categories, with ten individuals at the very top of the social spectrum. By contrast, at Apple Down, West Sussex, 69 per cent (of 121 
Table 4.1 Interpretations of social hierarchy based on the quality of gravegoods found in inhumation graves (based on Arnold 1981, Christlein 1973 and Shephard 1979)

\begin{tabular}{|c|c|c|c|c|c|}
\hline $\begin{array}{l}\text { Social } \\
\text { rank } \\
\text { (Arnold) }\end{array}$ & $\begin{array}{l}\text { Quality } \\
\text { group } \\
\text { (Christlein) }\end{array}$ & $\begin{array}{l}\text { Social } \\
\text { hierarchy } \\
\text { (Shephard) }\end{array}$ & $\begin{array}{l}\text { Male grave } \\
\text { goods }\end{array}$ & $\begin{array}{l}\text { Female grave } \\
\text { goods }\end{array}$ & $\begin{array}{l}\text { General } \\
\text { significance }\end{array}$ \\
\hline \multirow[t]{2}{*}{ unfree } & \multirow[t]{2}{*}{ A } & $\mathrm{E}$ & $\begin{array}{l}\text { No } \\
\text { gravegoods }\end{array}$ & $\begin{array}{l}\text { No } \\
\text { gravegoods }\end{array}$ & Poor graves \\
\hline & & $\mathrm{D}$ & $\begin{array}{l}\text { Knife buckle } \\
\text { (bow, axe) }\end{array}$ & $\begin{array}{l}\text { Glass beads, } \\
\text { knife, buckle }\end{array}$ & \\
\hline \multirow[t]{2}{*}{ ceorls } & \multirow[t]{2}{*}{ B } & $\mathrm{C}$ & Single weapon & $\begin{array}{l}\text { Single brooch, } \\
\text { short chain of } \\
\text { beads }\end{array}$ & $\begin{array}{l}\text { Average } \\
\text { wealth }\end{array}$ \\
\hline & & B & Weapon set & $\begin{array}{l}\text { Full female } \\
\text { dress set }\end{array}$ & Wealthy \\
\hline thegn & $\mathrm{C}$ & A & $\begin{array}{l}\text { Exceptional } \\
\text { full weapon } \\
\text { set, decorated } \\
\text { buckles, horse } \\
\text { equipment }\end{array}$ & $\begin{array}{l}\text { Full female } \\
\text { dress set with } \\
\text { silver or gilt } \\
\text { objects }\end{array}$ & $\begin{array}{l}\text { Exceptional/ } \\
\text { above } \\
\text { average } \\
\text { wealth }\end{array}$ \\
\hline
\end{tabular}

inhumations) would have been in Shephard's D and E categories, where only seven individuals could have been placed in ranks A or B. While it is possible that Deal was the burial ground for an exclusive sixth- or seventh-century elite, this is unlikely because it is at least materially comparable to many sites in East Kent: Lyminge, Bifrons, Sarre, Bucklands or Finglesham for example (Parfitt and Brugmann, 1997: 96). Apple Down is comparable to other sites in West Sussex, so this difference is more likely to be the result of regional access to wealth and objects, or regional attitudes to the deposition of that wealth which defined what went into or stayed out of the grave. This is not just a geographic phenomenon and is also seen chronologically. It was not until the seventh century that truly outstanding wealth was to be found in 'princely' graves like those from Asthall, Oxfordshire, Broomfield, Essex, Caenby, Lincolnshire, Coombe, Kent, Cuddesdon, Oxfordshire, Prittlewell, Essex, Sutton Hoo, Suffolk, or Taplow, Buckinghamshire. There was also more regional variation in brooch types in the sixth century - a phenomenon connected to the emergence of the 'Heptarchy', the seven Anglo-Saxon kingdoms of the Historia Anglorum (Northumbria, Mercia, East Anglia, Essex, Kent, Sussex, and Wessex), though the political reality was more complex than that, with many micro-kingdoms, fluctuating authority and instability - and the appearance of distinctive regional costumes, triggered by the evolution of regional identities that emerged alongside 
these kingdoms (Hines, 1994). The same is true for weapons: fewer weapons are found from graves created in times of greater conflict, such as the early sixth or early seventh centuries. As a result, Härke argued, weapons may have been easily dispensed with in quiet times and more common in graves when they were less critical to the living community (Härke, 1994).

Objects were not just tied to social rank and had a complex role to play within society because they were bound up with images, memories and associations, and suggested different things to different people (Joy, 2009; Gosden and Marshall, 1999). Many objects were symbolic, like swords or weapon sets, which may not have been associated with actual warriors, but with ideas about gender roles, identity or appearance (Härke, 1994). As a result the displays of social status cannot have been as rigid and fixed as Shephard, Arnold or Christlein imagined, varying not just because of social rank, but also due to time of death and who buried the dead. Equally, a gilt brooch was not just a badge of wealth for an adult woman; it was also used in the creation and/or display of regional and personal identities (see, for example, Hakenbeck, 2009). Some individuals have been discovered buried with heirloom objects, many with considerable wear or damage from heavy or long-term use (Eckardt and Williams, 2003; White, 1988; White 1990). These may have been seen as amulets or of personal significance and so became inalienable from the dead person's identity in the eyes of the funeral party. Perhaps they were significant for a particular group of people at a particular time: Grandmother's brooch inherited and buried with a young woman or child, for example. All of these concepts were interconnected and the decisions that led to the creation of a grave assemblage would have been an amalgamation of ideas, concepts, images and negotiations shared by multiple people; buried objects became 'enchanted' and enmeshed with perceived personae (Gell, 1992). The choice of whether to dress a corpse, and what to dress it in or what to furnish the grave with, were as personal and specific to individuals as they were particular to kin groups, communities, regions or cultures. For this reason the wealth within a grave has to be understood within its community context. The location of a grave and its relationship to other graves provides evidence about how a community saw and used a grave after earth had filled it.

While social status is a difficult phrase (having often been used to describe rank), grave wealth is too crude a concept to properly describe the act of dressing a corpse, cutting a grave and celebrating a funeral. Wealth is only part of why objects were selected for display, whereas societal situations and relationships define the significance of an individual to others, and so display must be intended for an audience 
specific to a location and period. This social status is a mutable concept and a good way to think about part of a grave and cemetery's messages, but it must be considered alongside other factors like gender, age and location within the broader cemetery organisation. Such ephemeral concepts cannot be derived from burial wealth alone. Moreover, while it is possible to criticise the segregation of cemeteries into ranks based on the numbers of objects, it is not possible to study cemeteries without conceding that wealthy burials were significant. Many marked out specific people and events, reconstructing personhood post mortem and marking out a particular episode as important (Theuws, 2013). The inclusion of rich, elaborate or just specific, artefact assemblages was used to create a persona for the deceased, but in the creation of a significant, shared ancestor the entire burial community made a statement about their own communal identity.

In Chapter 2, the seventy-two-grave cemetery at Wakerley, Northamptonshire, was discussed in detail. The site was subdivided into three separate burial plots each demarcated by gaps larger than $3 \mathrm{~m}$. For this site it was also possible to plot the distribution of wealthy graves, defined for the statistical investigation as furnished graves containing men with two or more weapons and women with two or more brooches (after Stoodley, 1999; Härke, 1994; see Chapter 1). Interestingly, this more detailed investigation showed clustering at $3 \mathrm{~m}$ for the cemetery and $5 \mathrm{~m}$ for furnished burials, suggesting some further internal organisation where the eastern plot had a group of multiple furnished graves positioned deliberately close together, but the western and central plots did not; in each case just two wealthy graves were in close proximity (Figure 4.1). This positioning constituted an internal cluster, or core, to that eastern plot and shows differential organisation between zones of the cemetery.

Nick Stoodley (1999: 131-2) observed that the cemeteries at Andover and Petersfinger were both organised around the high-wealth individuals who were the central focus of burial plots. However, the three plots at Wakerley present us with two different types of internal organisation. All three plots contained a mixture of furnished and unfurnished graves. In the eastern plot, a core of the furnished burials created a central focus, but the remaining two plots were more diffuse, having no obvious core. These two types of burial plot can be seen across the corpus of early Anglo-Saxon cemeteries. For example, the hundred graves at Berinsfield were organised between two or more burial plots, with the northern plot separated spatially and with N/S oriented graves. This northern group contained a core of three clustered furnished burials (Figure 4.2). Berinsfield's plot B contained four furnished burials positioned together at its core, with three more buried on the eastern edge suggesting the 


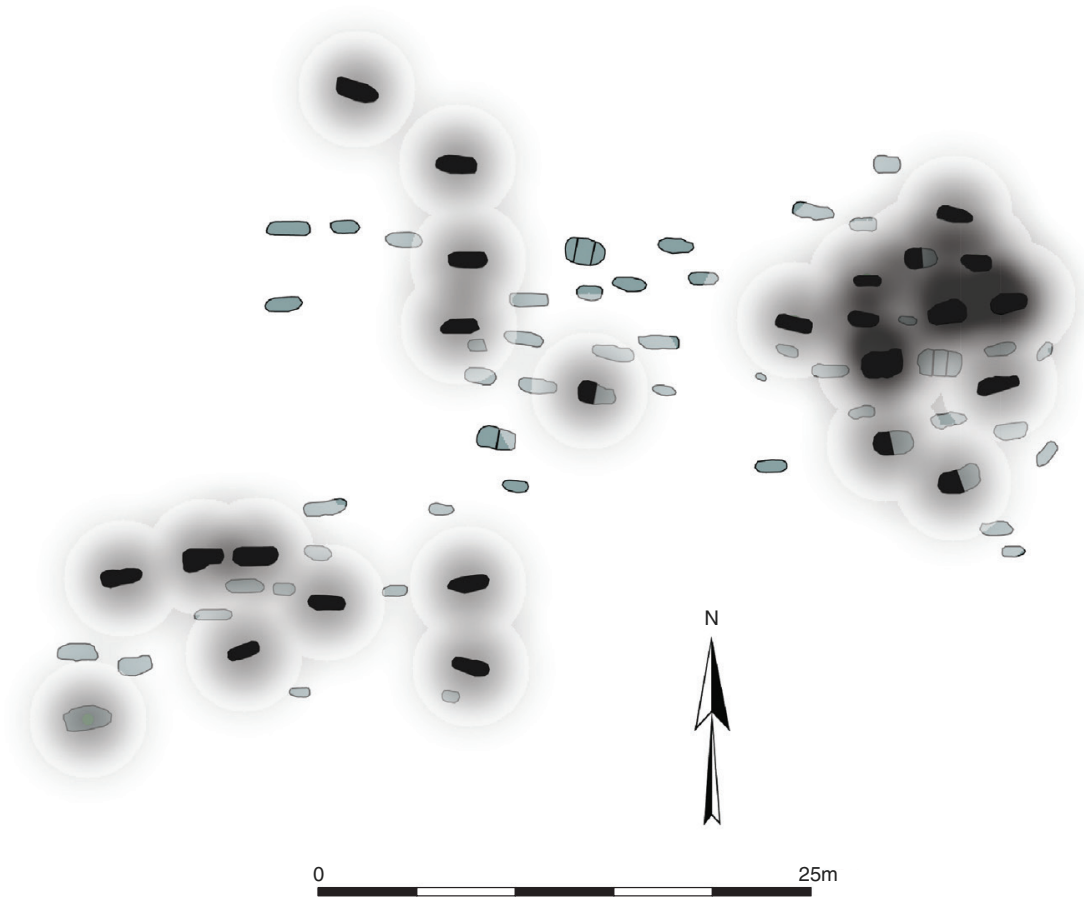

Figure 4.1 Wakerley, Northamptonshire: the spatial distribution of furnished graves clustered at $5 \mathrm{~m}$. This clustering was evident in the eastern graves, which can be seen here deliberately grouped together as a core group within this plot.

focus of a third group, plot C, but many of these graves have been lost during quarrying to the south of the site.

Apple Down is another cemetery in which mortuary practice centred on a core of furnished or wealthy burials (Figure 4.2). Three of the wealthiest graves from the site were located at the heart of the cemetery and surrounded by less wealthy, but mostly furnished, inhumations clustered at $5 \mathrm{~m}$ (see Chapter 1). Three further furnished burials were distributed around the site, seemingly at random. However, the richest burials were placed at the centre of the group of E/W oriented graves and so they were at the core of the sixth-century cemetery. These graves were not just furnished, but similar and comparatively wealthy: graves 10, 13 and 14 contained gilded saucer brooches, sets of beads, and knives, while grave 14 also included a gilt great square-headed brooch. A similarly wealthy male burial nearby, grave 63, contained a spear, bucket, seax, firesteel, buckle, knife and set of tweezers.

The excavation at West Heslerton, East Yorkshire, identified 201 individual graves. To the south the cemetery was divided into two plots, 
0

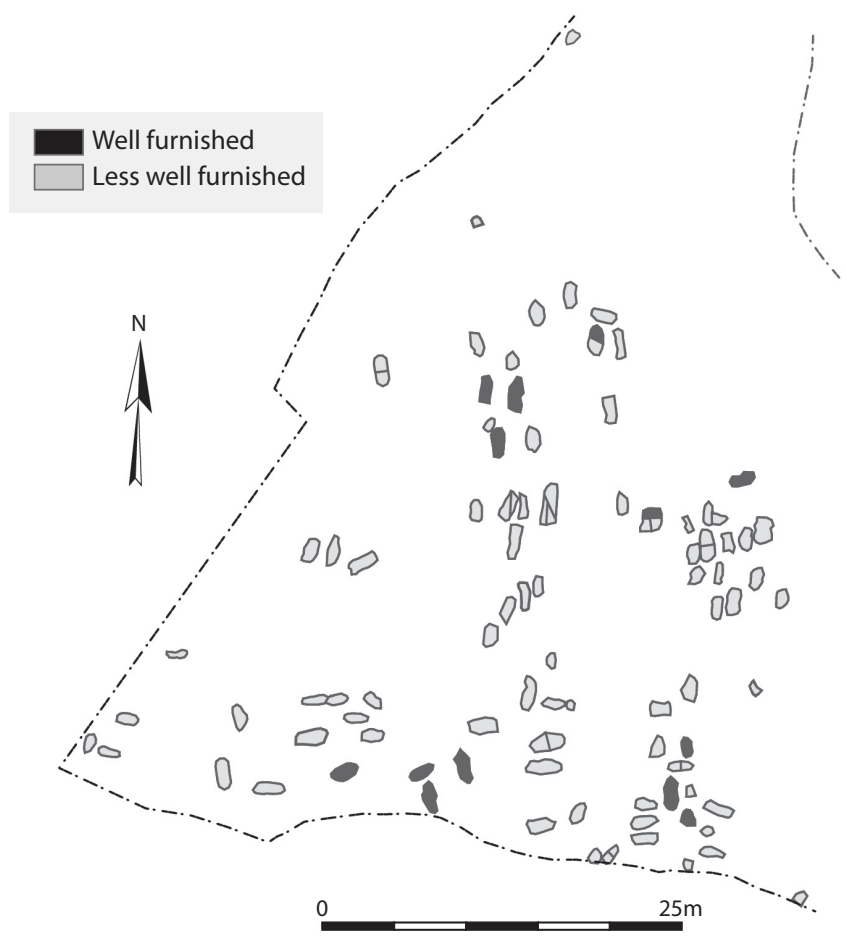

Well furnished Less well furnished

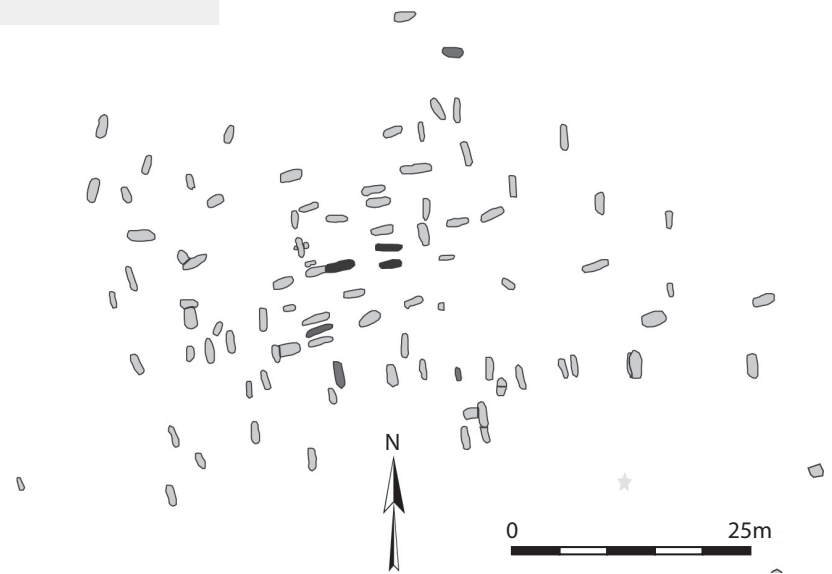

Figure 4.2 Core groups of furnished graves were also seen at Berinsfield, Oxfordshire (top), where groups of three or four graves made up clusters within the different plots. At Apple Down, West Sussex (bottom), the three wealthiest graves were found together in the centre of the E/W oriented burials. 
each on either side of a Bronze Age ring ditch. In the north of the cemetery was found a less dense group of graves also divided into two widely spaced groups. The largest plot, A, had a core of wealthy burials consisting of five double or triple weapon graves (Figure 4.3), and these included one central burial with a sword, shield and two spears, as well as a number of female graves with great square-headed and cruciform brooches. These brooches are significant because the common dress items in the cemetery consisted of annular or penannular brooches and beads,

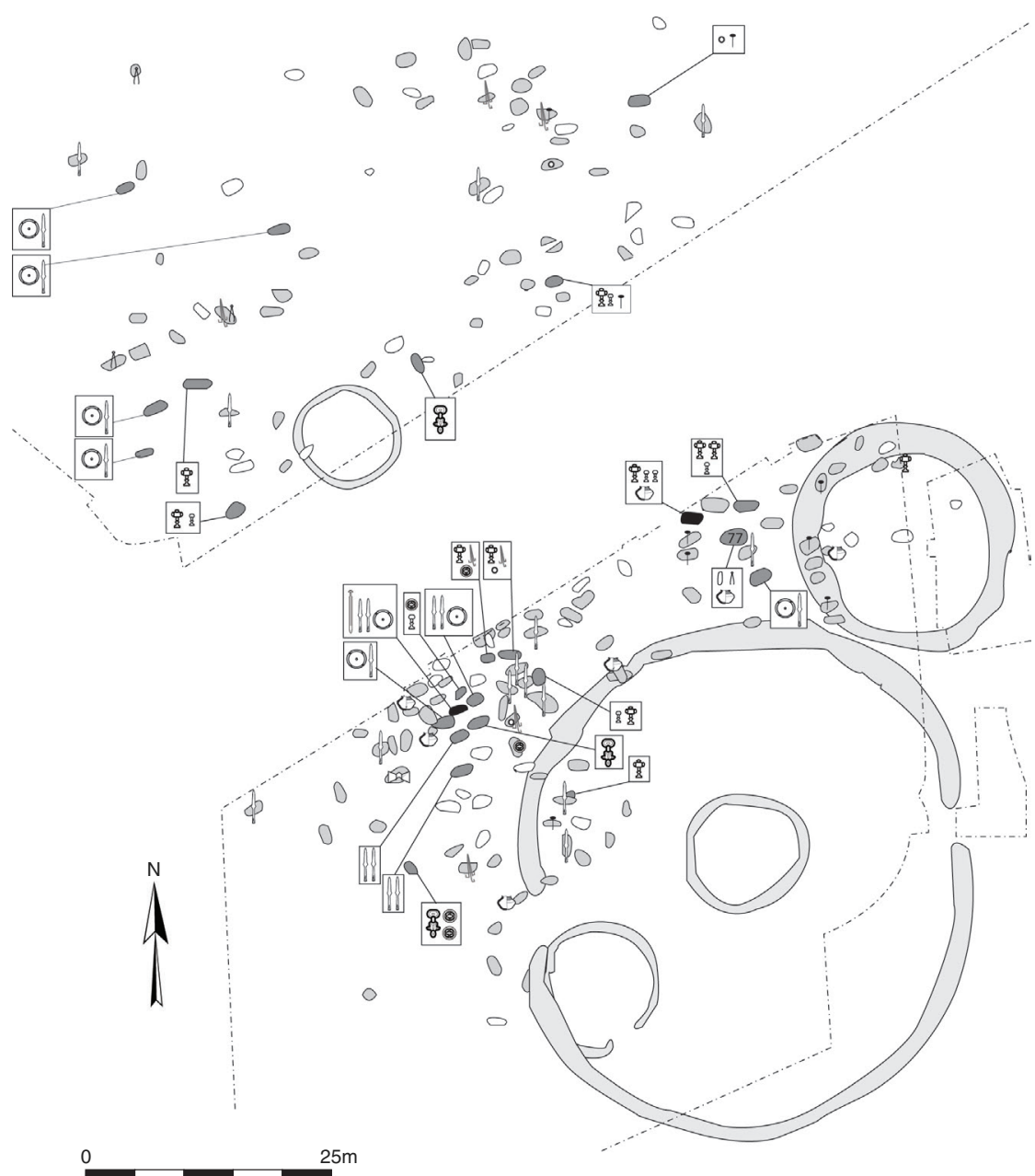

Figure 4.3 At West Heslerton, East Yorkshire, the cemetery was divided into four plots. To the south were found clustered plots of graves; and the largest group, A, contained a core of furnished burials in the centre. 
or a buckle and knife. This core was surrounded by more graves that had common brooch types, or single weapons, and these burials contained knives, buckles, beads or brooches. The smaller plot to the east also had a core of burials just outside the western edge of a Bronze-Age ring ditch. This group consisted of two female burials, with cruciform and small-long brooches, and two weapon burials, with another grave, 77, in the middle. Grave 77 was not a weapon grave, but was notable for its unusual assemblage that included two knives, one $79 \mathrm{~mm}$ and one $151 \mathrm{~mm}$ in length. The burial also included a buckle, awl, tweezers, bluegreen glass cullet from a cone beaker, the remains of three pottery vessels and a whetstone. This range of goods was unique within the cemetery and is certainly unusual, suggesting an artisan but one buried in a central and significant location. The northern groups of graves had no obvious centres, although two weapon burials and two cruciform brooch burials were placed in close proximity on the south-western edge.

At Great Chesterford, Essex, there were also a number of different plots of burials, signalled by the density and orientation of graves, and the wealthy N/S-oriented graves seemed to constitute core burials in plot A. In the middle of the cemetery there were two particularly wealthy graves, grave 122, which contained a globular pot, Roman coin, glass claw beaker, spearhead, sword and shield boss, and grave 142, which held a spearhead, pottery vessel, shield boss and horse (Figure 4.4, bottom). Six other furnished inhumations were found in close proximity. This cluster constituted a core of wealthy burials at the heart of a spatial group of inhumations (plot A). Similarly, to the south of this burial plot was found a second, smaller plot with six furnished burials creating a core (plot B). The N/S graves at Great Chesterford clustered at $3 \mathrm{~m}$, and were organised around two large multi-directional plots in the middle of the cemetery. Plot A's core graves were N/S oriented and formed a centre; plot B's core graves were not all oriented the same way, but nonetheless a core of wealthy inhumations was located in the middle of this group of burials (Figure 4.4). To the south of plot B a less dense cluster of burials contained furnished graves but no obvious core. Similarly, to the north of plot A there were a number of less dense burials with furnished graves throughout and no obvious cores or pattern to the orientation of graves.

The contrast between plots A and B at Great Chesterford shows that not all plots had similar cores of graves, and these central areas may have been identified in any number of ways. Ripley $\mathrm{K}$ analysis of the 117 graves at Norton showed statistical significance at $7 \mathrm{~m}$, and consequently the Norton cemetery was organised into two plots, an eastern and a western plot, divided by a single $5 \mathrm{~m}$ gap (Chapter 2). The eastern plot, B, contained fifty-eight inhumations and the furnished graves were found in two groups. Three of these graves were to the west on the edge 
Furnished

Less furnished
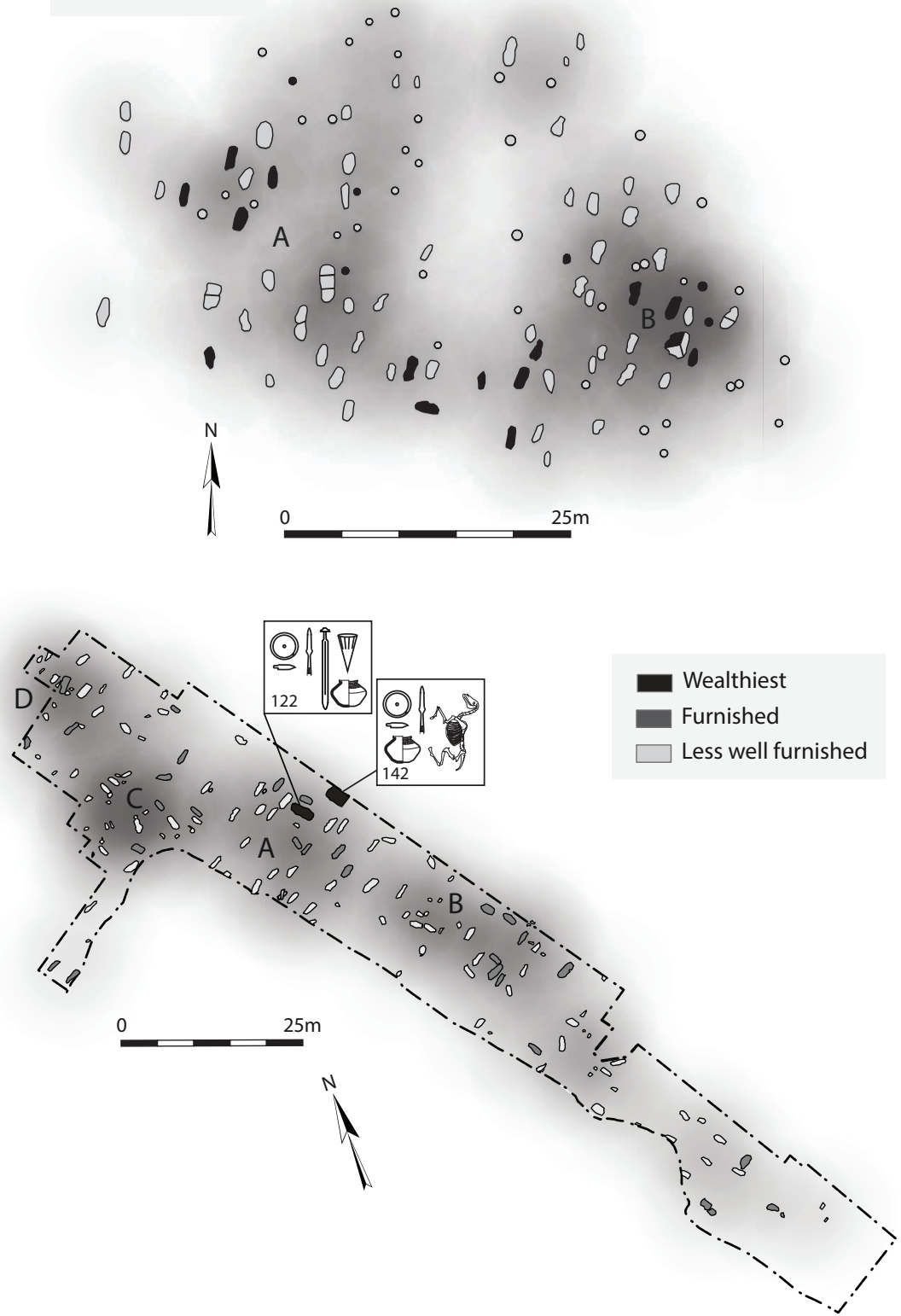

Figure 4.4 Norton, northern Cleveland (top), and Great Chesterford, Essex (bottom). These two cemeteries contained different core groups of burials. At Norton, the furnished graves in plot B were split between two groups, one in the highest-density areas and one to the western edge of the group. At Great Chesterford, both plots A and B had a core of furnished burials, but plot A centred around two particularly wealthy burials, 122 and 142. 
of the plot and a further six, or seven, in the central area within $7 \mathrm{~m}$ of each other. This area was the densest in the cemetery and so was a core for this cemetery, with multiple burials placed deliberately in the space (Figure 4.4). The western plot contained fifty-nine inhumations with ten furnished graves dispersed around the plot, and the four westernmost inhumations formed a higher-density group, but there was no obvious centre to this plot. Only in one plot at Norton did the furnished burials form a core, but the graves were much more dispersed than at West Heslerton or Great Chesterford, which fits the general character of this cemetery with more widely separated graves.

Similarly, at Holborough, west Kent, thirty-nine graves were excavated as part of rescue excavations in the 1950s, by which time many more to the south had been lost. These graves appear to have been loosely clustered into two plots of burials, but in fact this was not statistically significant (Figure 4.5); the thirty-nine graves covered the same
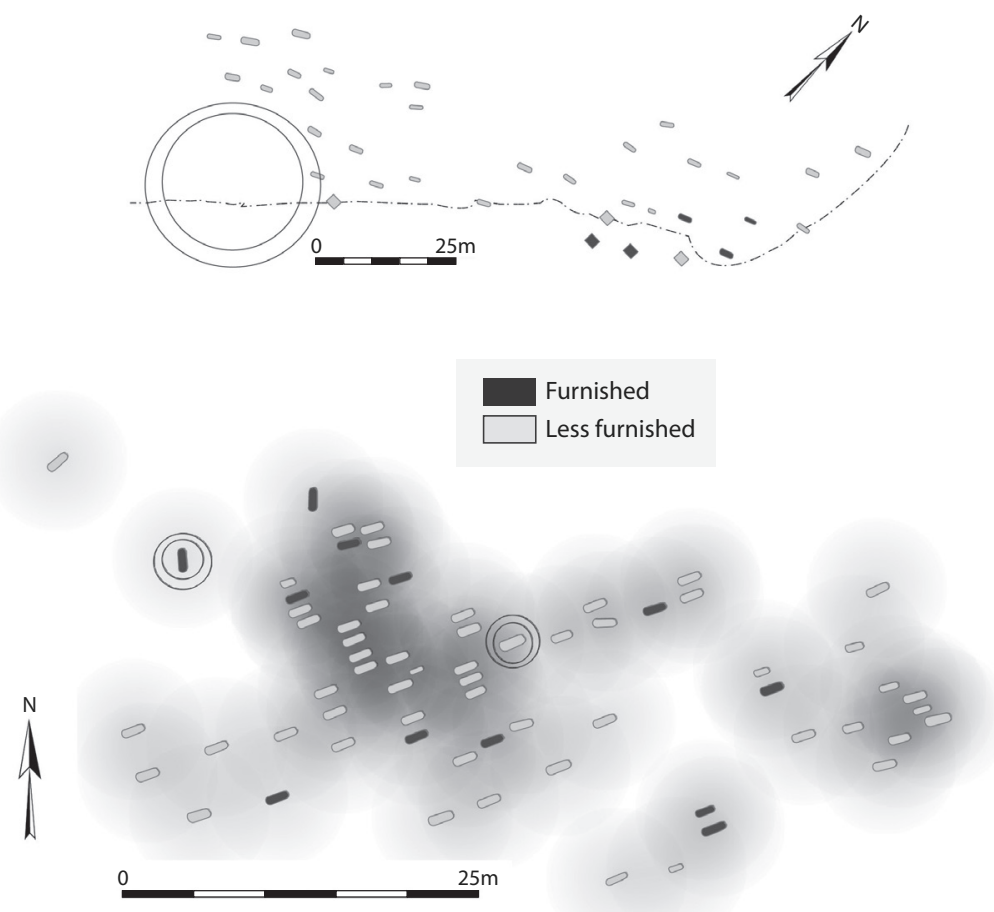

Figure 4.5 Holborough, western Kent (top), had just five furnished burials, all found towards the eastern end of the site. Leighton Buzzard III, Bedfordshire (bottom), had one large group of graves or plots with several smaller groups of graves to the east. The furnished graves were dispersed around the site with no obvious clustering. Both Holborough and Leighton Buzzard were seventh-century sites. 
area as the whole of the diffuse Norton cemetery with its 117 graves (Evison, 1956). Only the eastern part of Holborough contained any furnished burials, with just five graves in close proximity to the south-east. Equally, Leighton Buzzard III, Bedfordshire, consisted of sixty-eight graves (Figure 4.5; Hyslop, 1964). It was more ordered than Norton, but was more dispersed, with two plots clustering at $5 \mathrm{~m}$. Plot A was a large group of burials to the west, and plot B was a much smaller plot to the east. The furnished graves from this site were dispersed around the cemetery and showed no internal clustering whatsoever. Leighton Buzzard III was a seventh-century cemetery and, like Holborough, it had a much more dispersed internal organisation. Seventh-century cemeteries, like Holborough, Leighton Buzzard II or III and Bargates, and second-phase zones in earlier cemeteries, like those at Lechlade or Polhill (see below), seem less likely to be focused on a core of higher-status graves, with the exception of the royal graves at Street House (Sherlock, 2012). By way of contrast, many fifth- and sixth-century cemeteries (for example, West Heslerton, Great Chesterford, Deal or Bergh Apton) had a cluster of graves which formed a central focus for the cemetery. Other fifth- and sixth-century sites, like Apple Down, Wakerley and Great Chesterford, had been organised around multiple plots with different structures within each plot. In either case one plot, or one core of one plot, consisted of notably wealthy individuals.

Not all cemeteries had a core of wealthy graves, but many did contain notable burials. Four obvious examples are Lechlade, Orpington, Oakington and Finglesham (Chapter 6). These four sites had a dispersed set of high-status graves, a combination that we also saw in the plots at Great Chesterford, Apple Down or Berinsfield. These furnished graves were still the focus of specific commemorative activity. For example, Orpington in west Kent, a sixth-century site with sixty-four excavated graves (Palmer, 1984), is significant because the furnished burials were located around the core, rather than within the heart of the cemetery, and they seemed to snake around a small barrow burial which made a central focus for the cemetery (Figure 4.6, right; see also Chapter 1; Stoodley, 1999: 128). Intriguingly, this barrow burial was not furnished at all, but seems to have been the focus of the furnished burials and the whole cemetery, cremations included, providing a central point around which the site continued to develop. This can be seen because the densest area of burial on the site encircled grave 23. Equally, grave 80 at Oakington was the focus of a tight cluster of inhumations which enclosed it (Figure 4.6, bottom). This group of graves was a central focus of the northern grave plot around the middle-sixth century. However, burial 80 was not a founder's grave because it truncated an earlier burial, grave 92 . The early medieval excavators of grave 80 came across 


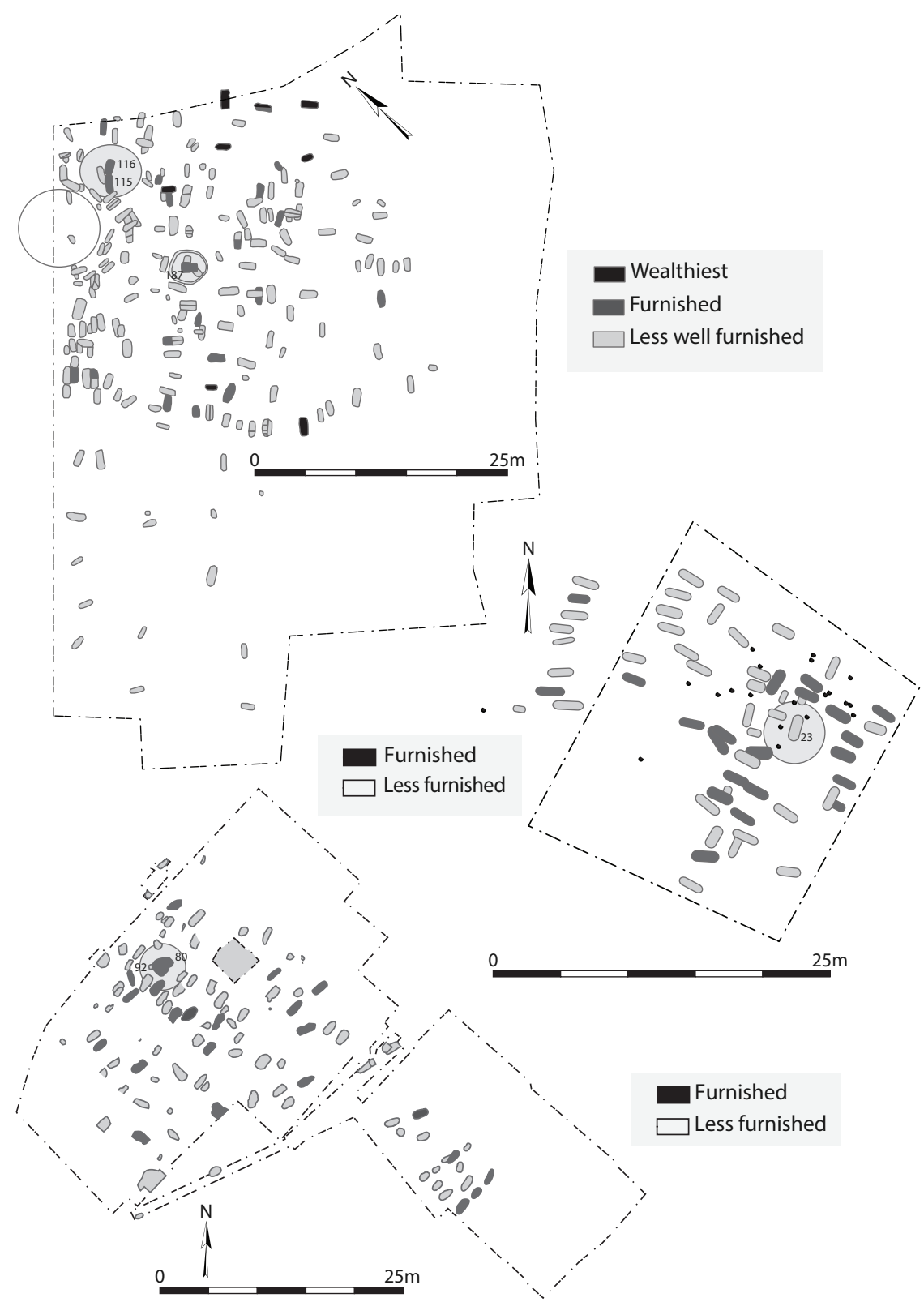

Figure 4.6 Lechlade, Gloucestershire (top), Orpington, eastern Kent (right), and Oakington, Cambridgeshire (bottom). At Lechlade the adjacent burials 116 and 115 , and nearby 187 , were central places around which other graves were placed in satellite positions. This phenomenon is also evident at Orpington, around grave 23 , and Oakington, with grave 80 . All of these graves probably had small barrows erected over them, marking their location. 
foot bones from the child in grave 92 and deliberately placed them back on top of the child's exposed leg bones.

A similar pattern is observed at Lechlade where furnished burials 116 and 115 were adjacent and formed a two-grave core within the northern burial plot (Figure 4.6, top; see also Chapter 6). Interestingly, the other burials in that area left a gap around the two graves, presumably because there had been a barrow over the top of them. These satellite graves enclosed the two central barrow burials, augmenting this focus of activity at the heart of the burial plot. A third inhumation, to the west of this pair of seventh-century graves, was inserted deliberately and dug directly into the overburden of the barrow. Burial 187 was also seventh-century and seems to have truncated the two earlier burials. This group has a ring ditch around it and a series of burials to the north and west actively enclosed them, highlighting this place for continued focus and consecutive inhumation. Other seventh-century burials at Lechlade may also have had small barrows on top of them, and so this pattern of activity was repeated for particular individuals throughout the site. The result was an ego-focused commemorative space which highlighted particular individuals instead of groups of important graves.

In all three examples, Orpington, Oakington and Lechlade, the sixth-century burials which focused later activity were probably mounded, and in each example later graves or cremations had been inserted directly into these features. At Orpington, these interleaved burials were of children and cremations (Stoodley, 1999: 128). At Oakington, they were children and prone burials; four prone burials were placed south of grave 80 in the area directly around, the barrow (Figure 4.6, bottom). At Lechlade, the interleaved burial was a third male inhumation dug into the barrow in the seventh century, and many of the graves immediately around this centre contained children. This small Anglo-Saxon barrow may have been purposely placed adjacent to a pre-existing Bronze-Age monument, around which other graves had been placed in satellite positions. In all three examples we speculate about the presence of barrows, and certainly the evidence presented by the satellite graves supports this hypothesis. None of these examples were discovered with a surviving barrow, but they were a central focus highlighted in a significant way. And so we venture that small mounds of earth marked each grave (Devlin, 2007b: 56) and these small barrows, witnessed by early antiquaries, do seem a logical way to have marked central focal points and significant graves (see below).

In these examples furnished, wealthy or mounded graves created central places which contributed to the subsequent structure of the cemetery. These graves could be gathered into a collective core group located within a space, or they might have formed individual places around 
which groups of burials were located. The two strategies for burial may say quite a lot about the community's decisions and it is of note that some communities placed emphasis on collective, multi-generational groups, whereas others seem to have structured burial places around particular egos.

The location of furnished graves was an important part of cemetery organisation, although this may have manifested in a number of different ways. In all of these cases, the furnished graves made places for mnemonic and commemorative activities and provided a structure, or grammar, for the site. But not all grave plots had these features, and in many cemeteries the second or third burial plots did not have a central focus, instead having a number of dispersed and furnished inhumations. Interestingly, the plots which contained a core, or central focus, were often richer than those with a dispersed core. This is seen at Wakerley, where the easternmost plot included a core of inhumations, and this was also where the majority of type II belt buckles and cruciform brooches were found (Figure 4.7). This grave plot, with the

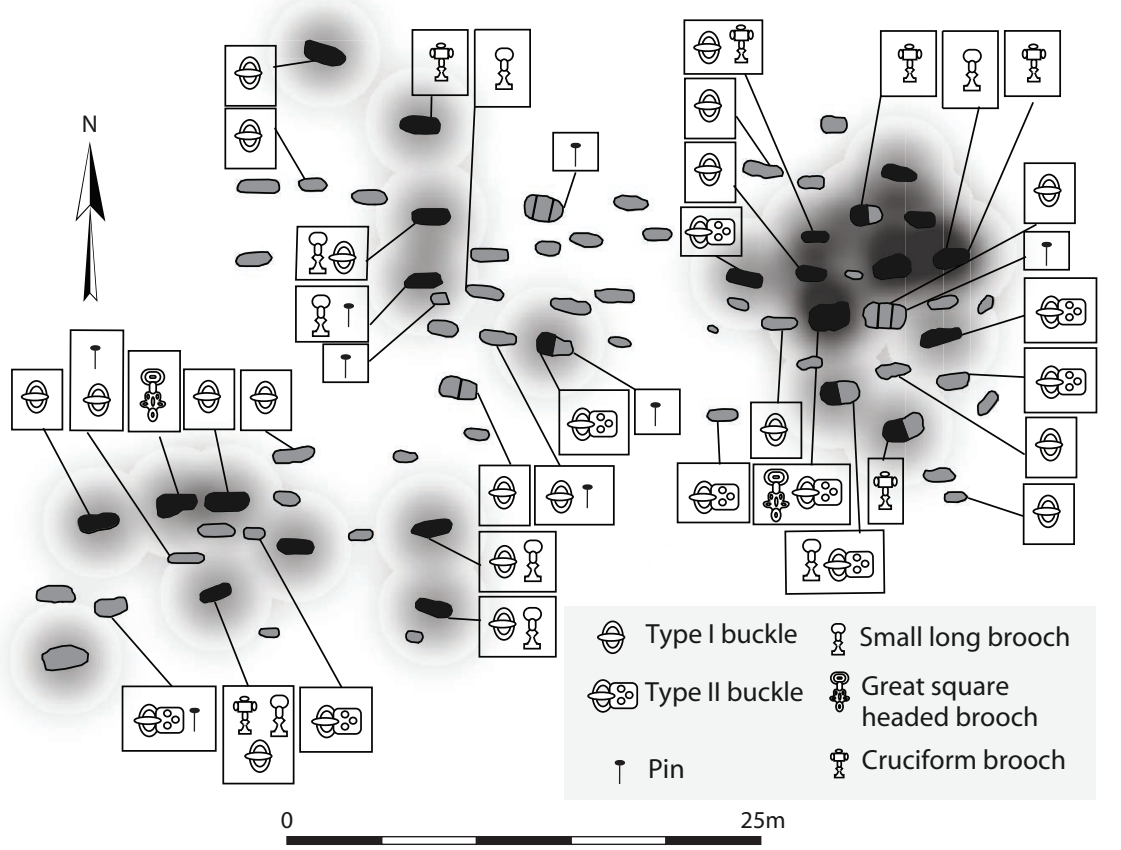

Figure 4.7 At Wakerley, Northamptonshire, the core inhumations were found in the eastern plot, corresponding with the more display-oriented objects; in this case the type-II belt buckles and the cruciform brooches were more common in the eastern burials. 
core, contained objects that placed more emphasis on display compared with the other contemporary burial plots. The same is true at Lechlade and Oakington, where the richer graves were found in the plots that contained central barrow burials. The physical situation of a grave was key to understanding individual graves and cemeteries, but it is also important to consider other leitmotifs like age and gender, which are central to social perceptions.

\section{Sex and gender}

Among the most influential contributions of theoretical archaeology has been the development of sophisticated ways to think about gender differences (Gilchrist, 1991; Barrett, 1988; Sørensen, 1992) - not just as the biological sexes, but as identities and physical bodies, both of which need to be negotiated and managed during the progress of a life course (Gilchrist, 2012). In British archaeology, gender developed as an important topic for research in the 1990s after a series of influential investigations (for example: Gilchrist, 1991; Gero and Conkey, 1991; Moore and Scott, 1997). Early Anglo-Saxon female objects, brooches for example, had been a central component of research, but the focus of that research was firmly set on regional object types, style and chronology (Brush 1988; Dickinson, 1976; Welch, 1983). There was no investigation of the woman within the costume or the man behind the shield boss. However, in the 1990s, there were two scholars who stood out as leaders in this field, Sam Lucy (1997) and Nick Stoodley $(1999 ; 2000)$. Stoodley conducted a large, quantitative study based on the investigation of forty-six cemeteries; he indicated that women's burials were not any richer than men's but that the rituals associated with women placed more emphasis on the body and on life course and that femininity transcended social status - unlike masculinity, which was tied to social rank. Lucy's investigation was more qualitative and she identified five genders: male with gravegoods, male with female gravegoods, female with gravegoods, female with male gravegoods and burial with no gravegoods.

Both Härke (1997) and Stoodley (1999) considered early AngloSaxon gender identities to be without rigidity. They regarded them as fluid negotiations taking place within a 'frontier-like' society where lifetime roles and daily routines had to be completed regardless of social distinctions. Such a situation required a degree of transaction between sexes and it is this flexibility, they argued, that gave rise to definite gender identities expressed during the construction of funerals. In this context display was used as a reaffirmation of social differences largely absent in life (Härke, 1997; Stoodley, 1999). Härke questioned the identification of manifold gender identities and, returning to the data, he suggested 
that the individuals assigned third and fourth gender distinctions could be explained as part of the error margins for skeletal sexing. This he estimated to be between 5 and 10 per cent, with only 1.16 per cent of males found with dress items and 0.24 per cent of females with weapons (based on a database of forty-five cemeteries, Härke, 2011). This problem is particularly significant at some cemeteries, like Empingham II, which contained a number of third and fourth gender burials. Unfortunately, Empingham II was plagued with post-excavation problems, such as missing objects and doubtful associations between some objects and graves (Timby, 1996: 6).

The sex-gender phenomenon is also seen in well-excavated sites, such as grave 104 at Berinsfield. Skeletally an adult male, the occupant was found with two small-long brooches and amber beads, more often associated with a female gender (Boyle et al., 1995: 52). Another example, grave 144 from West Heslerton, included a female skeleton with a spear (Haughton and Powlesland, 1999b: 249). These individuals were not otherwise treated differently, or located in 'deviant' burial locations on the edge of cemeteries or plots (Reynolds, 2009), as we might expect if they occupied unusual social categories - this is well attested in the anthropological literature, where third and fourth genders are accepted but separated by social norms (Metcalf and Huntington, 1991). Perhaps defining third genders in early Anglo-Saxon archaeology is a circular argument - the assumption is that weapons were associated with the male sex and therefore were masculine artefacts, but when a weapon is identified with a member of the female sex she has taken on a different gender. If we reduce this to basic principles then this circumstance proves only that weapons were not exclusively associated with men, and so perhaps the mesh of concepts bound up with a spear included masculinity but also other important elements which became especially important when buried with a woman. An unusual object, in this case a spear, may have promoted a number of different overlapping elements, for example, asexual or sexualised female identities, and so interpreting this subtlety in terms of gender divisions is at best simplistic. In two cases at West Heslerton, graves 144 and 164, women were buried with a spear, but the absence of brooches neither confirms nor refutes that they were also dressed in male clothes; many females were buried without surviving artefacts and presumably organic fasteners held their costume in place.

The concepts enmeshed with gender identities are complex and multi-faceted, linked with age (Stoodley, 2000) and the expression of identity (Lucy, 1997). Gender is an important part of social life and as a result scholars have tried to find patterns within the archaeological record by looking at changes in costume or burial practice. Ellen-Jane Pader took a multi-variant approach connecting age, body positions 
and artefact assemblages, but obvious patterns are not common (Pader, 1982). One of the most obvious is in the layout of a cemetery, and for some sites limited patterning is evident.

The location of male and female graves has been identified as significant to the organisation of some cemeteries, for example Howletts in Kent, Lechlade and Polhill (Lucy, 2000: 132) or Broadstairs and Worthy Park (Stoodley, 1999: 135). All of these sites organised different genders into different areas, but many of these sites were complex or
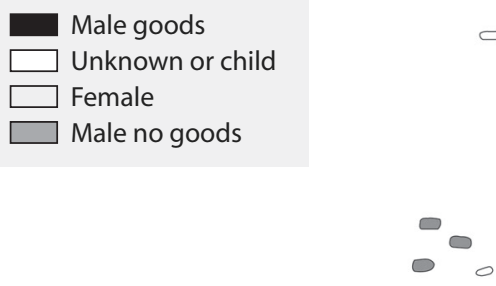

$\diamond$
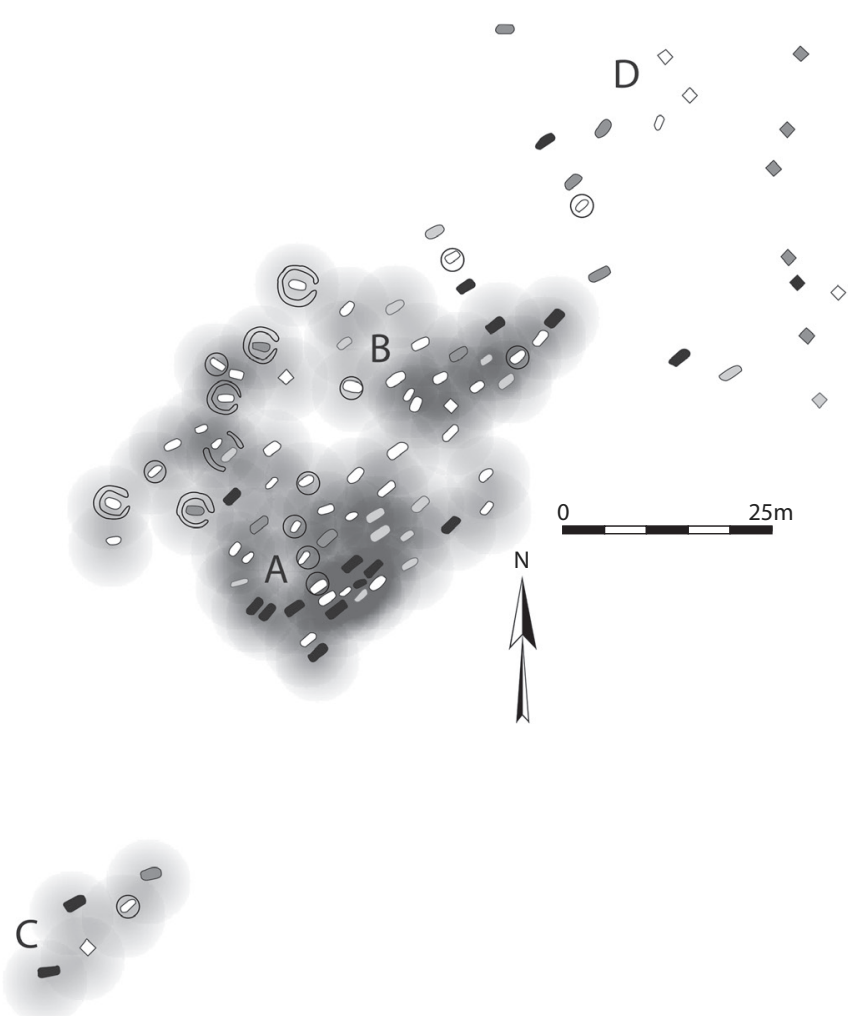

Figure 4.8 Polhill, Kent, was divided into three plots of graves, A, B and C, with one group of homogeneous graves, D, to the north. Plot A contained a specific concentration of male-weapon burials to the south. 
have been only partly excavated. Regardless, a considerable endeavour has been made to identify gender patterning in early Anglo-Saxon cemeteries - in cemetery organisation at Polhill and Westgarth Gardens, or in small numbers of comparable graves at sites like Empingham II or Lechlade, for example. However, few sites actually contained patterns. Cemeteries like Pewsey, Bergh Apton and Finglesham show no obvious difference and are by far the norm. Indeed, Lechlade cemetery also shows little evidence of gender differentiation at a site scale. These types of investigation serve to demonstrate the considerable variation within the archaeological record (Huggett, 1996; McHugh, 1999). Gender has rarely been considered as a structuring principle within groups of graves or plots, and so it is the social unit that arranged the plots which may be of some consequence in gender distinction. With gender display, social differences might be apparent because of localised decisions, such as who prepared a body or selected a location for the grave, and so specific practices might only have been common among specific sub-social groups. Patterns within some cemeteries are perhaps more interesting than patterns across all cemeteries because local patterns tell us about local decision-making, power relationships, behaviours and local histories. Localised patterning emphasises the power of the individual and community as the agent(s) of early medieval cemetery architecture.

The separation of small numbers of gender-specific graves is seen elsewhere, for example with the graves of a specific gender, or biological sex, in the seventh- and eighth-century cemetery at Polhill, Kent. Polhill is a large site with 130 burials in 111 graves (Philp, 1973; 1979; 2002). The gender division was evident in its internal organisation: some graves were clustered at $5 \mathrm{~m}$, making up two plots, a large plot to the southwest (A) and a smaller one to the north-east (B), and there was a group of statistically dispersed graves north-east of plot B. The excavators identified a series of six ring ditches to the north-west of the site and these, as with contemporary Kentish cemeteries like Deal, Finglesham or Dover Buckland, are probably seventh-century. A group of eight male-gendered weapon graves were found to the south of plot A, and to the north-east of these were found five furnished female graves, deliberately positioned and creating a gender-divided core of furnished burials (Figure 4.8). This group of graves was accompanied by four burials with small barrows over the top (Philp, 1973; 1979; 2002). Interestingly, this core of significant inhumations was divided loosely into two halves structured by gender. Plot B had no core, and there was no evidence of gender separation. However, the dispersed graves to the east had two groups of male graves; to the north was a group of males without weapons, and to the east a row of seven male graves, of which only one included a weapon. In this dispersed zone the unfurnished male graves 
were on the peripheries of the site, separated from the two plots (A and $\mathrm{B}$ ) and also from the deliberate gender segregation seen among the wealthy graves at the heart of plot A.

The pattern seen in plot A at Polhill is seen elsewhere in early AngloSaxon cemeteries, for example, the two small sites at Broadway Hill, Hereford and Worcester, and Winterbourne Gunner, Salisbury and South Wiltshire (Figure 4.9). Broadway Hill is a late-fifth- and sixth-century cemetery consisting of eight graves and was identified during quarrying (Cook, 1958). This site had a strong gender-oriented organisation, with male graves in the west and females in the east. Similarly, Winterbourne Gunner, consisting of ten graves, was also a late-fifth- and sixth-century cemetery with males to the west and women to the east (Musty and Stratton, 1964). Other sites, like Lyminge II in Kent, also showed strong gender patterning within specific parts of the site. However, all of these sites were fragmentary, and excavation comprised fewer than 50 per cent of the graves originally present; so these patterns may be found only in localised areas of the cemetery (Hurd, 1913; Hurd and Smith, 1910; Warhurst, 1955).

The deliberate grouping of male burials was also seen in the latesixth- and seventh-century furnished graves. At Deal, seven of the easternmost burials formed a line of male graves, and all dated to this latest phase (Figure 4.10). It has been proposed that this was an expression of divisions within rank (Stoodley, 1999: 128), but it may also have been the result of a subdivision of the male household. At West Heslerton, 201 graves were excavated and subdivided into statistically significant plots (see Chapter 2). Plot A was the wealthiest and contained a cluster of sixth-century weapon burials. Williams (2007: 116) suggested that the objects placed within these graves were a response to the memory of previous graves and included a range of material selected to identify similarity and masculine status. Their organisation is reminiscent of Orpington (see Chapter 2), the weapon graves were placed in a $\mathrm{T}$ shape and each was given a slightly different range of equipment including multiple spears, shields and a sword - showing their martial equality but marking each one as different. Interestingly, just a few metres to the east of these a group of four single-weapon spear burials were positioned in a cluster. There were no comparable groupings for the women's graves, which were positioned around these two groups. None of the other plots in this cemetery contained such a marked gender division, and plot $\mathrm{A}$ at West Heslerton was the wealthiest and largest plot in the cemetery.

Strong gender patterning was also present within Westgarth Gardens, Suffolk (West, 1988; Penn and Brugmann, 2007). Stoodley suggested that gender played a major role in the organisation of this 

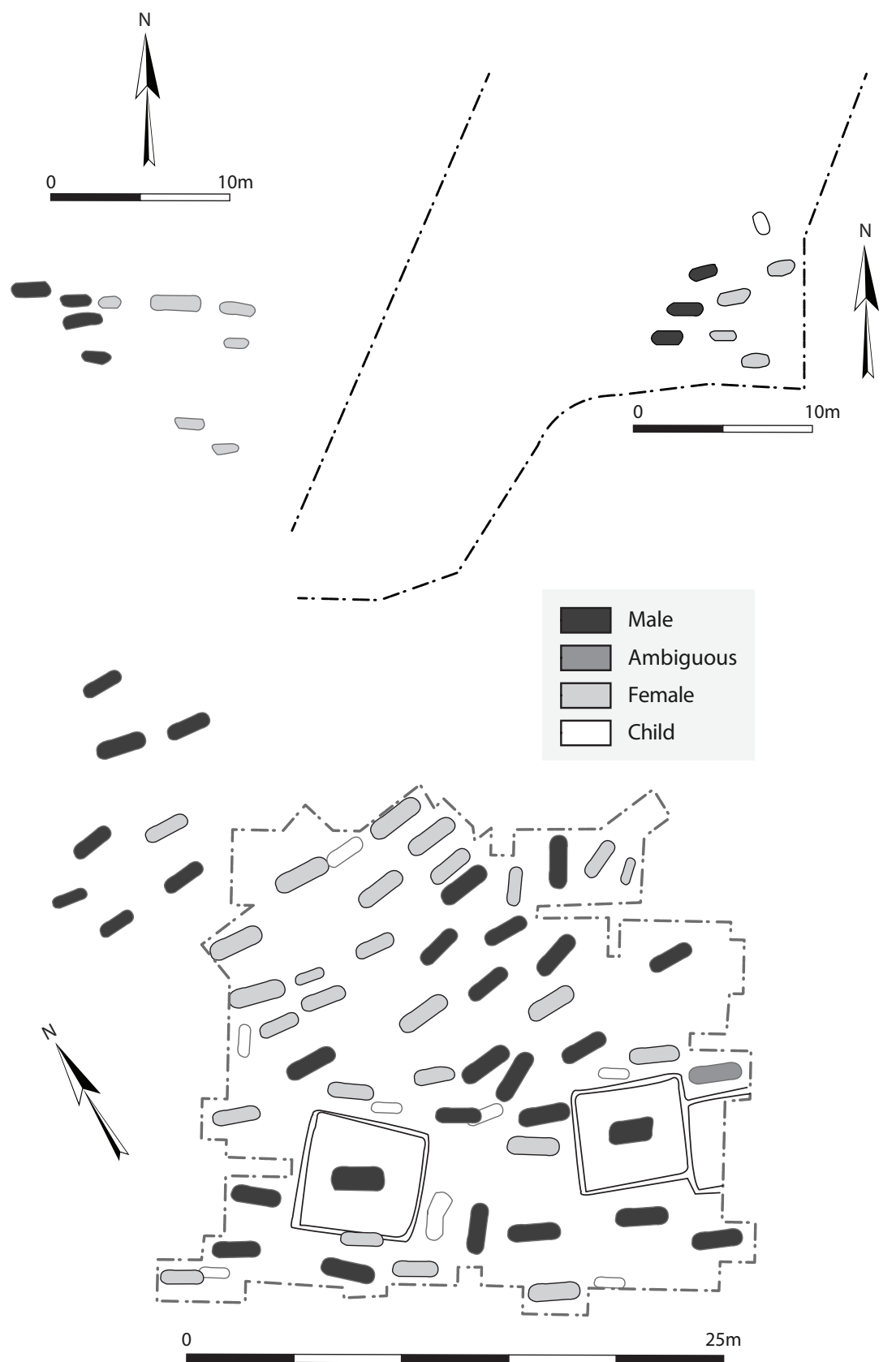

Figure 4.9 Broadway Hill, Worcestershire (top left), Winterbourne Gunner, near Salisbury, Wiltshire (top right), and Lyminge II, Kent (bottom). In each of these cemeteries male and female graves were located in different parts of the site, creating a gender zoning within the known burials. 


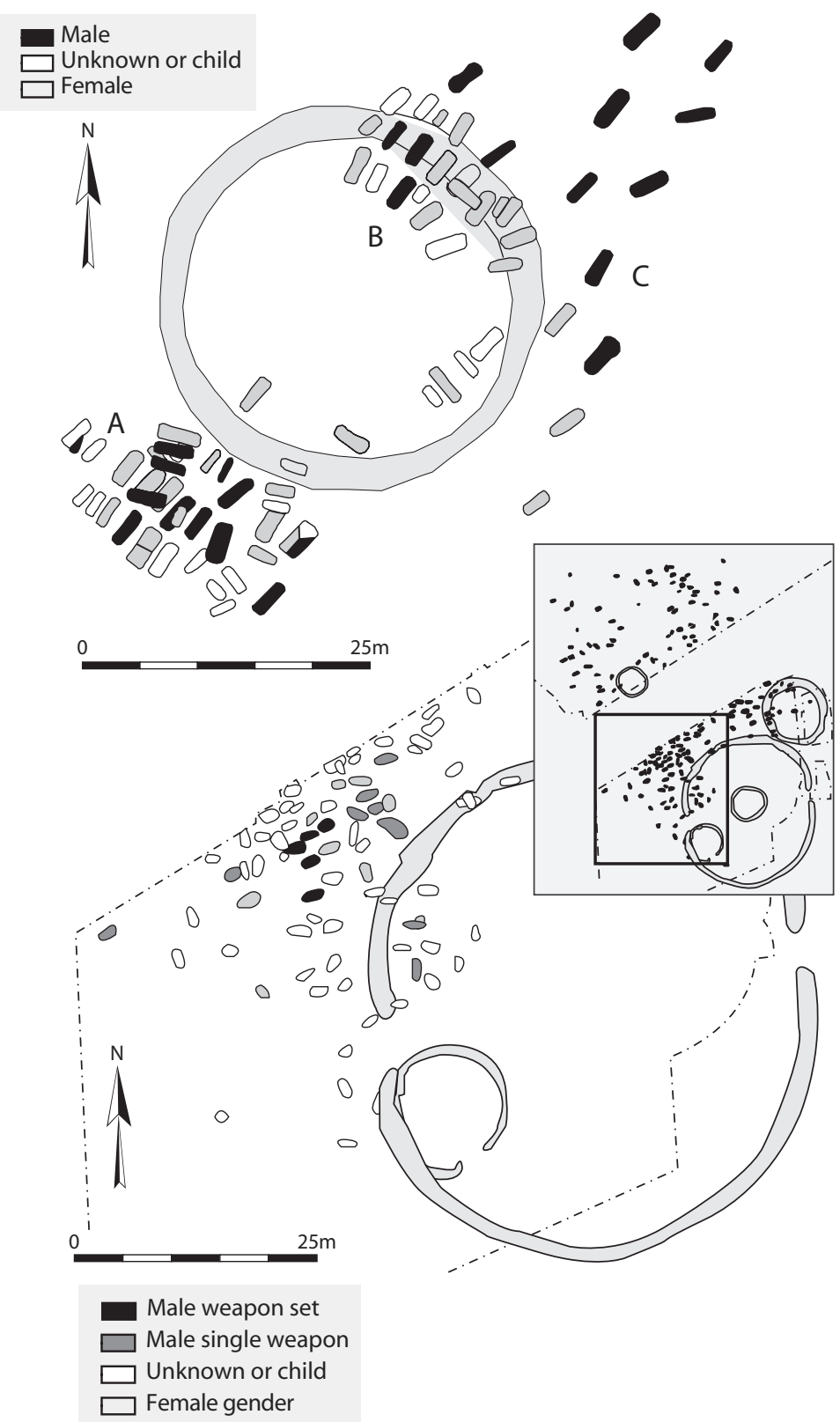

Figure 4.10 Deal, eastern Kent (top), and West Heslerton, East Yorkshire (bottom). At Deal, the two sixth-century plots, A and B, showed some internal clustering of gendered graves, with groups of males and females. This pattern was most evident in the later eastern group $\mathrm{C}$, where all of the male graves were found in the northern area of the plot. At West Heslerton, the males with weapon sets were found in a group in the centre of the largest and wealthiest cluster of graves. 
cemetery (Stoodley, 1999: 131). Penn and Brugmann agreed but argued that Westgarth Gardens cannot be organised into different plots for men, women and children (Penn and Brugmann, 2007: 86). However, the sixty-six burials, in sixty-one graves, do show strong gender segregation, with women buried to the north and men to the south. Interestingly, children's graves were placed between these two areas (Figure 4.11). This site does not appear to have been organised into different plots, but this was also not a complete cemetery, being one part of a larger site. This excavated area probably included just the core of the cemetery, identified because the metalwork was discovered with a metal detector, and subsequently seven male burials have been found to the north. A further burial was found $50 \mathrm{~m}$ to the east of the excavated cemetery, but the intervening area was not excavated (West, 1988: 2).

The Westgarth Gardens pattern is also seen elsewhere. Berinsfield is a good example of segregated zoning among elite inhumations: the core graves in plot $\mathrm{A}$ all had female artefacts, the core in plot $\mathrm{B}$ consisted of three male burials and just a single female grave (Figure 4.11) and the core in plot $\mathrm{C}$ consisted of two females and one male. This arrangement focused on gender affinity, and was the deliberate result of decisions and negotiations made by the people who attended each funeral and who contributed to the cemetery architecture. Not all cemeteries had cores divided by gender - Norton and Wakerley, for example, showed no internal subdivision - and so the decision to segregate focal space by gender must have been the result of community-specific decisions affecting only individuals from affluent - and/or dominant - families.

There were probably identity motivations to divide cores (or plots) along gender lines, and small-scale gendered distributions were also evident in seventh-century cemeteries such as Bargates (male), Fonaby, Lincolnshire (female) and Snell's Corner (male) (Stoodley, 1999: 135). This bias or clustering in favour of one gender may have been the consequence of prejudice embedded in the expression of belonging to a particular local group who preferred to express male or female characteristics in funeral narrative. Specific costume was favoured for display in a mortuary drama whose most numerous participants would have been the immediate community and regional elite. This emphasis was intended to highlight the progress of a specific lineage though one gender line, defining a principal family as either matriarchal or patriarchal. In this scenario, members of the community who 'married in', or otherwise came from outside, would not have been placed in a central position. The differentiation shown was aimed at the regional audiences to whom the accentuation of gender-determined lineages would have been significant. 

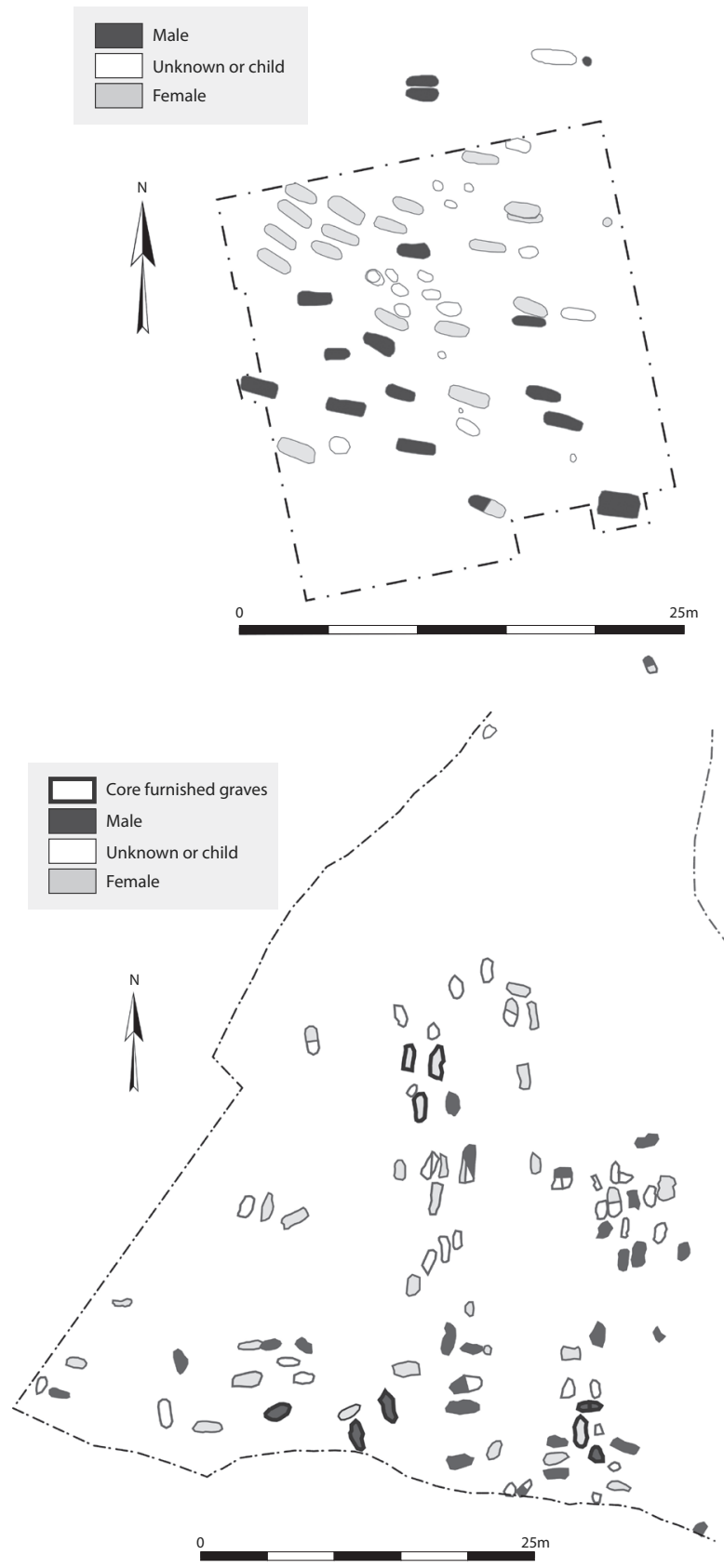

Figure 4.11 Westgarth Gardens, Suffolk (top), and Berinsfield, Oxfordshire (bottom). The burials at Westgarth Gardens seem to have been divided into male and female spaces. This excavated area was probably a core area within a large plot and a larger cemetery. The segregation of elite burials is seen at Berinsfield too. 
Another way that gender was emphasised can also be seen by comparing cemeteries. This can be seen clearly in a sample of twenty cemeteries with good skeletal and artefact data (Table 4.2). In these cemeteries, five show significant proportions of gendered artefacts to biological sexes, and a further site shows borderline significance. For example, from the identifiable adult skeletons at Apple Down, forty-three were male and forty-four were female. This was not an unusual ratio; however, sixteen male skeletons were buried with weapons and only six female skeletons with female-gendered gravegoods. This is statistically significant and shows a deliberate localised bias against interring females with gendered objects.

Apple Down is the only cemetery from this sample with a bias against the female gender; the other four or five sites show the reverse bias, with a greater proportion of female to male skeletons found with female-gendered artefacts. These sites include Broughton Lodge (Nottinghamshire), Castledyke South (North Lincolnshire), Norton and Sewerby. West Heslerton is a borderline case and, with a ratio of sixty-nine females to twenty-four males, nearly three times the number of gendered-female burials to male burials, it may be that this is a

Table 4.2 The ratio of sex to gender and its statistical significance

\begin{tabular}{lrrrrlll}
\hline Cemetery & \multicolumn{2}{c}{$\begin{array}{c}\text { Sex } \\
\text { (skeleton) }\end{array}$} & \multicolumn{2}{c}{$\begin{array}{c}\text { Gender } \\
\text { (goods) }\end{array}$} & \multirow{2}{*}{$\begin{array}{l}\text { Fisher's Test } \\
p \text { value }\end{array}$} & Significant \\
\cline { 2 - 5 } & M & F & M & F & & \\
\cline { 2 - 4 } Apple Down & 43 & 44 & 16 & 06 & 0.041 & Yes \\
Barrington & 58 & 40 & 22 & 21 & 0.241 & No \\
Beckford B & 34 & 55 & 26 & 31 & 0.236 & No \\
Berinsfield & 30 & 32 & 19 & 11 & 0.130 & No \\
Blacknall Field & 29 & 32 & 18 & 26 & 0.318 & No \\
Broughton Lodge & 6 & 12 & 37 & 25 & 0.044 & Yes \\
Castledyke South & 51 & 69 & 13 & 35 & 0.045 & Yes \\
Deal & 17 & 16 & 18 & 16 & 0.550 & No \\
Dover & 129 & 117 & 58 & 54 & 0.500 & No \\
Empingham II & 43 & 38 & 44 & 52 & 0.209 & No \\
Finglesham & 76 & 75 & 27 & 27 & 0.546 & No \\
Great Chesterford & 22 & 43 & 18 & 37 & 0.530 & No \\
Kingsworthy & 32 & 39 & 19 & 12 & 0.098 & No \\
Lechlade & 52 & 89 & 29 & 57 & 0.369 & No \\
Market Lavington & 10 & 09 & 09 & 07 & 0.550 & No \\
Norton & 32 & 27 & 10 & 41 & 0.0002 & Yes \\
Sewerby & 11 & 12 & 04 & 17 & 0.044 & Yes \\
Wakerley & 18 & 31 & 18 & 33 & 0.523 & No \\
West Heslerton & 15 & 20 & 24 & 69 & 0.0509 & Borderline \\
Westgarth Gardens & 24 & 22 & 21 & 12 & 0.217 & No \\
\hline
\end{tabular}


definite bias in favour of the female gender. In the above discussion, gendered artefacts are taken to include male graves with a weapon, such as a sword, shield or spear, and female graves with a single brooch or pair of brooches. To avoid the chronological drop-off in brooch burials at the end of the sixth century, seventh-century graves with pairs of dress pins and significant pendants (for example, see Finglesham) have been included as gendered graves.

Note that Table 4.2 uses Fisher's exact test, which is more accurate than chi-square, both because it is an exact test, not an estimate, and because it is also accurate with small numbers. The equation for Fisher's exact test is $(p=(\mathrm{a}+\mathrm{b}) !(\mathrm{c}+\mathrm{d}) !(\mathrm{a}+\mathrm{c}) !(\mathrm{b}+\mathrm{d}) ! / \mathrm{n} ! \mathrm{a} ! \mathrm{b} ! \mathrm{c} ! \mathrm{d} 1)$ (Fisher, 1922). For this test, significance is taken to be a $p$ value of 0.05 .

Alongside the localised bias in favour of a specific gender expression, seen above, there is also evidence for differences in the treatment of one biological sex over another, and two sites from this sample of twenty are numerical outliers for biological sex ratios. Both Great Chesterford and Lechlade contain nearly twice as many women to men, although the proportions of gendered graves remain within expected norms. If we consider these two sites to be abnormal, then the ratio of male-to-female sexed skeletons from the remaining eighteen sites is 658:690 (48.8 per cent men, 51.2 per cent women). Interestingly, in the 2011 census the British population was 63.182 million, 31.029 million men (49.1 per cent) and 32.153 million women (50.9 per cent) (Office of National Statistics, 2012: tab 1). The Great Chesterford and Lechlade variation is statistically significant, and so these populations were not the result of a random variation but of deliberate behaviour. The female corpse was more likely to be interred in these sites and, given that whole areas of early Anglo-Saxon cemeteries are not defined by sex or gender differences, as discussed above, this is unlikely to be the result of under-excavation.

Contingency tables 4.3 and 4.4 outline the data for Great Chesterford and Lechlade respectively. The predicted value was calculated using the proportion of male-to-female graves from eighteen cemeteries and calculating the expected proportion based on the size of each site. The null hypothesis for these tests asked if the proportion of men to women was an expectable average or 'normal' value based on the sample. To check the results given by Fisher's exact test, Pearson's chi-square

Table 4.3 Male-to-female contingency table: Great Chesterford

\begin{tabular}{llll}
\hline & Males & Females & Totals \\
\hline actual numbers & 43 & 22 & 65 \\
predicted numbers & 32 & 33 & 65 \\
total & 75 & 55 & \\
\hline
\end{tabular}


Table 4.4 Male-to-female contingency table: Lechlade

\begin{tabular}{lccc}
\hline & Males & Females & Totals \\
\hline actual numbers & 52 & 89 & 141 \\
predicted numbers & 69 & 72 & 141 \\
total & 121 & 161 & \\
\hline
\end{tabular}

was also used to test this hypothesis at $P=<.05$. It was rejected at Great Chesterford with a $P$ value of $p=.05\left[\mathrm{X}^{2}(1, \mathrm{n}=65)=3.8\right]$, and also at Lechlade, where the $P$ value was $p=.04\left[\mathrm{X}^{2}(1, \mathrm{n}=141)=4.18\right]$, so the larger populations of women at these sites were significant and were probably the result of deliberate cultural behaviours.

Anglo-Saxon burial customs allowed patterns in the placement of gendered graves, but these are not as pronounced as the patterns displayed in the large cremation cemeteries on the Continent. Süderbrarup in Angeln Schleswig-Holstein, Germany, contained 1,234 second- to sixth-century graves with predominantly male gravegoods and a biological population which included 51 per cent male graves versus ten per cent female graves; the rest remained unsexed or were juvenile (Bantelmann, 1988; Wahl, 1988). By contrast, Bordesholm, near Kiel in Schleswig-Holstein, contained over 5,000 cremations with predominantly female gravegoods, including a range of brooch types. It was in use from the Roman Iron Age to the fifth and sixth centuries but, with just one martial object, a single scabbard chape, this was a predominantly female-gendered cemetery (Saggau, 1981; Saggau, 1986; Wahl, 1988). This comparison highlights an important difference: early Anglo-Saxon cemeteries expressed limited organisation by gender and, unlike these large continental cemeteries, they did not serve whole regions. Anglo-Saxon differentiation was specific to a particular localised elite, who interred their dead as core burials at the centre of grave plots. Internal patterns were evident at Broadstairs I, Lyminge II, Winterbourne Gunner, Bargates, Fonaby, Snell's Corner, Lyminge, Deal, Orpington, Berinsfield, West Heslerton, Westgarth Gardens and Polhill - with a specific bias towards female-gendered burials at Broughton Lodge, Castledyke South, Norton and Sewerby, and possibly at West Heslerton too. In these sites the placement of furnished burials sent a message to a regional audience, just as it did in continental migration-period cemeteries; but, rather than highlighting the joint inheritance of a community, these funerals focused on a specific lineage, the local elite family, and conveyed the value that the family placed on gender in this locality, so that gender expression is contingent on social group and location. Indeed, at Apple Down it was the male lineage which dominated the cemetery. At Great Chesterford and at Lechlade, however, there were significantly more women in proportion to men than would 
be expected from a single community. Presumably, women's bodies were specifically transported to these sites for burial, a phenomenon which is also seen in age differentiation.

\section{Age}

Developments in gender archaeology have led to an increased focus on life course and, in particular, infancy (see Sayer, 2014; Crawford, 1999, 2000, 2011). There are differences in the distribution of infant graves in later Anglo-Saxon sites. Minsters and the later-emerging parish churchyards were more likely to attract infant burials than contemporary field cemeteries, and many infant burials were found around the church or under the eaves, for example, at Raunds, Northamptonshire, Cherry Hinton, Cambridgeshire, and Tanner's Row, West Yorkshire (Sayer, 2012; Hadley, 2011). When looking at earlier sites, a number of authors have suggested that the style of a child's burial and their body position often mimic those of adults in close proximity, either just the women or both men and women (Pader, 1982). However, there remains a problem. Few studies have looked at the distribution of ages in cemeteries with the intention of deriving patterns. Many reports simply state that children are under-represented in early Anglo-Saxon cemeteries (Buckberry, 2000; Lucy, 1994). Penn and Brugmann even warned against such investigations based on the distribution of graves at the partly excavated Norton cemetery (Penn and Brugmann, 2007: 88). Stoodley has investigated the ages of furnished graves at Deal, Pewsey and Norton. He observed just one pattern at Norton and noticed that 'in each of the main plots the burials of children, but also youths, are on the outer edges, with the adult burials making up the core' (Stoodley, 2011: 654).

In many cemetery sites children, particularly infants, are absent or in fewer numbers than expected. For example, the cemetery at Alwalton, Cambridgeshire, was a small cemetery of around thirty-six graves with just two children, both found disarticulated in hollows and pits having been disturbed (Gibson, 2007). But under-representation is only part of the situation, and there were significant differences between cemeteries in how infants' and children's graves had been managed (Sayer, 2014). In the majority of cases, Norton included, there was no obvious patterning to the distribution of specific age groups, even children, who were consistently distributed throughout early medieval cemeteries. However, perhaps for underlying social reasons, several cemeteries stand out.

As we saw in Chapter 1, at Apple Down the burials of infants and children seem to have been spread around the cemetery, but there was a specific concentration of burials in the middle of the site, clustered alongside a similar concentration of adults over the age of 45 (Figure 4.12). 

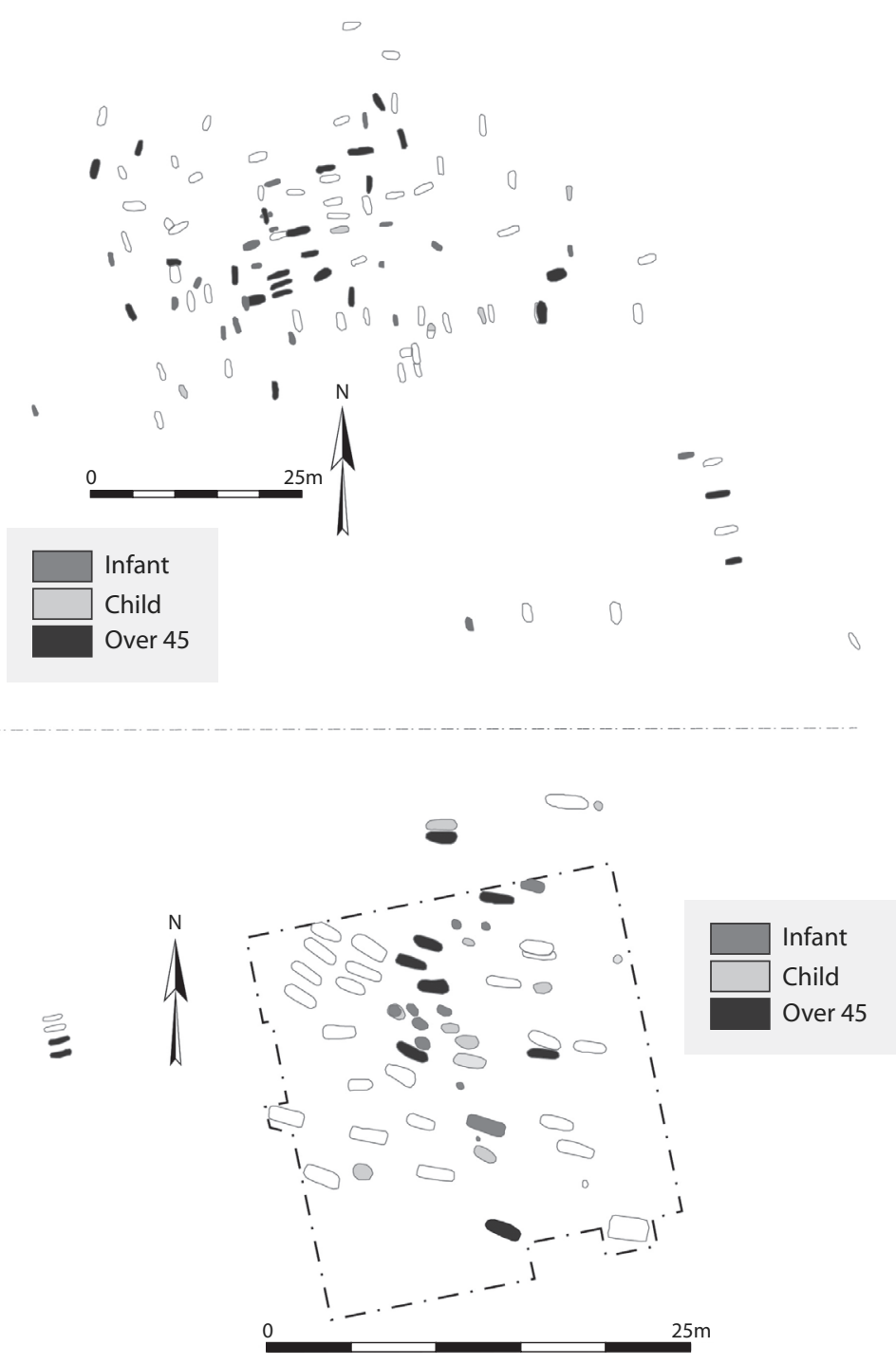

Figure 4.12 Apple Down, West Sussex (top), and Westgarth Gardens, Suffolk (bottom). These two cemeteries had a concentration of infants, or infants and children, associated with graves of older adult. 
Many of these adults were also part of the furnished core at the centre of the cemetery and most of them were on the same orientation, a strategy that defined the central area of the site. Westgarth Gardens contained a similar pattern, with a core of furnished burials divided into a male (south) and female (north) zone. This core seems to have included a cluster of older adults, and in its centre was placed a group of infants and children. Similarly, the Oakington cemetery, in Cambridgeshire, had a particular distribution of infants and children in the south of the site (Figure 4.13). In these three cases the sites included infants and children distributed throughout, but with a particular concentration in one area, sometimes associated with older adults. This pattern was also seen at Morning Thorpe where plot B, the western of two wealthy plots, had a figurative barrier of furnished graves defining its extent and inside the boundary established by these graves were the smallest graves, suggesting that many infants and children could be found within the middle of this plot. Unfortunately, however, bone preservation was very poor (see Chapter 6).

At these three sites children were placed within central, or off-centre, zones within the cemetery. At Great Chesterford, Essex, a different pattern was evident. Great Chesterford was excavated between 1953 and 1955 and revealed 161 inhumations and thirty-three cremations (Evison, 1994). As outlined in Chapter 2, the site was organised with a recurring pattern based on the orientation of graves with tight clusters, and interestingly infant and child graves were found in particular zones (Figure 4.13). To the north a cluster of thirty-five children occupied a wide area of approximately 35 sq.m interspersed with adults, but with two specific concentrations of infants in two zones: one consisted of seven infants, the other of eight. A second cluster of twenty infants and children was placed in the south of the cemetery, although this was interspersed with adults. There were also specific clusters of infant graves. The largest, to the north of this cluster, contained seven graves. Importantly, what defined these two zones of infant burial was the comparative absence of infants and children in the cemetery's central area. This centre consisted of the furnished adult graves on an E/W orientation and the two most richly furnished graves.

Children and infants are often under-represented in cemeteries (Crawford, 1991; Buckberry, 2000), and so it is interesting that there were particular concentrations of them at Great Chesterford, Morning Thorpe, Westgarth Gardens and Oakington. In these sites there was a demographic over-representation of infants, where 11 per cent mortality was expected (Crawford, 1993; 2000; Sayer, 2014), and so they appear to have been central places to inter infants, and adults may have carried the children for some distance to be interred in a specific place. It is 


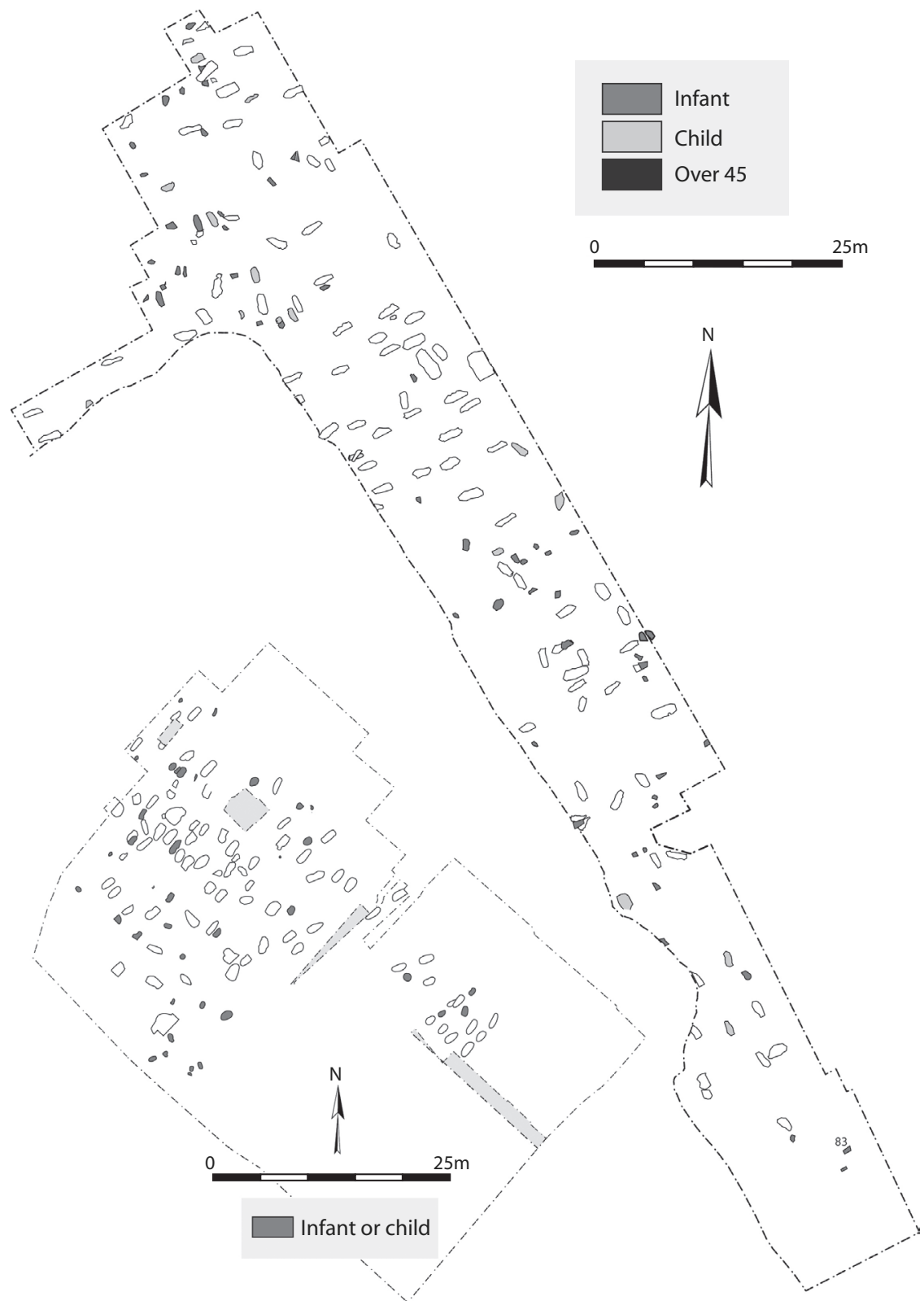

Figure 4.13 Oakington, Cambridgeshire (lower left), and Great Chesterford, Essex (right). These two cemeteries had a distribution of infants and children throughout the cemetery and in particular zones. There were very few infants in the central areas at Great Chesterford, but there were clusters of them in the surrounding plots and zones. Equally, there was a particular grouping of infants' graves in the southern part of the Oakington cemetery. 
interesting to see a similar pattern among women and infants, and in some places this post mortem mobility must have drawn women or infants from outside the immediate community, transported specifically for burial. Perhaps these social categories had more geographic mobility, moving between communities for marriage, or were associated with particular localised identity units.

\section{Grave structures, identity and grave robbing}

In East Kent there was a group of cemeteries, including Finglesham near Dover, Ozengell at Ramsgate, and St Peters and Bradstow School, both in Broadstairs, all of which had extra features used to distinguish particular burials (Hogarth, 1974). These features included two or more sockets cut out of the side of the graves, and ledges or sideboards cut into any or multiple-grave walls. A. C. Hogarth classified these structural features as integral to a grave and also identified external features such as postholes, ring ditches, curb slots or square ditches which are seen more widely across England. He considered that integral features should be regarded as later-seventh-century, although many examples, like grave 108 from Finglesham found with a ledge, are best dated to the first half of the seventh century, in the case of 108 because it contained a Marzinzik II.19b buckle (Marzinzik, 2003). The recent revised chronology of the mid-sixth and seventh-century graves simplified Marzinzik's typology and places many objects previously believed to be later into an earlier date range (Hines and Bayliss, 2013). This means that all of the graves with integral features can be dated to the whole seventh century and not just its twilight.

External features like ring ditches were certainly more common in these cemeteries, but they were also used in the sixth century (Shephard, 1979). The early antiquarian investigators William Stukeley, Bryan Faussett and James Douglas noted the presence of small mounds in many of their cemetery sites (Lucy, 1999: 101). Ring ditches were found in sites like Spong Hill (Hills et al., 1984), or associated with cremations at Apple Down, Orsett (Essex), Springfield Lyons or Stifford Clays (Essex) (Down and Welch, 1990; Tyler, 1996: 108-13). The fifthand sixth-century burials at Lechlade, Orpington and Oakington had small above-ground barrows which created a central place that focused attention. Without ring ditches these small mounds were not as obvious during excavation but their positioning over a grave meant that a space was left where other burials were not positioned because of the earth which surrounded them. These mounds were central places important to the cemetery narrative and so they also attracted satellite graves placed intentionally around them. The deliberate arrangement of space 
made barrows a focal point and a highly visual marker, used to convey messages about the deceased interred beneath them.

The sites from east Kent are particularly thought-provoking because these features were the foundation for structures, posts, canopies, planks or other visually identifiable features used alongside the preparation of a corpse and the furnishing of a grave in conveying the mortuary narrative. Sideboards, ledges and posthole features were deployed in these cemeteries, and probably others in Thanet and east Kent because each funeral influenced its participants. Within a regional setting, people from across these communities attended each other's funerals and witnessed the use of structures in funerary display; they also deployed them to enrich their own practice. Grave features are not well understood because many of the sites are only partially, or poorly, published (but see Avent, 1975: 4, 32; Evison, 1979: 69-83; Geake, 1997: 161-2; Hogarth, 1974; Klevnäs, 2013).

St Peters in Broadstairs was excavated between 1969 and 1971, in advance of an extension to the local authority refuse tip. Some 388 graves were identified and dated between the mid-sixth and mid-eighth centuries, with most dating to the seventh and eighth, although some of the cemetery remains unexcavated to the north-west of the site (Richardson, 2005: 15). The excavated graves from St Peters clustered with statistical significance at $4 \mathrm{~m}$, but at that distance only one separate group of graves is visible to the north. However, just like Apple Down, Berinsfield, Petersfinger and Great Chesterford, this large cemetery was organised by grave orientation. At St Peters this is subtle, but nonetheless deliberate, with grave orientation varying slightly between $\mathrm{E} / \mathrm{W}$ and NW/SE (Figure 4.14). This variation in axis divided the cemetery into three groups, B to the west with a NW/SE axis, A to the south with an $\mathrm{E} / \mathrm{W}$ axis and $\mathrm{C}$ to the north-east divided from the rest of the cemetery by a significant gap and consisting of a series of rows with graves on an E/W axis. Notably, graves located on the edges of each of these plots were likely to be oriented differently, or in an indeterminate way. This was also evident in between the western and southern plots of graves, a particularly high-density area. In the middle of plots A and B several graves were located with significant ( $4 \mathrm{~m}$ or more) gaps, and many of these had satellite graves enveloping them, evidence that there were once barrows raised there. Interestingly, the graves with integral features were located in the highest-density areas of the site, particularly in between plots $\mathrm{A}$ and $\mathrm{B}$, with only one associated with a grave that may have had a barrow (the only published, but much reproduced, plan is Hogarth, 1974). These integral-feature graves were positioned between barrows, between plots and not associated with the most prominent graves. 


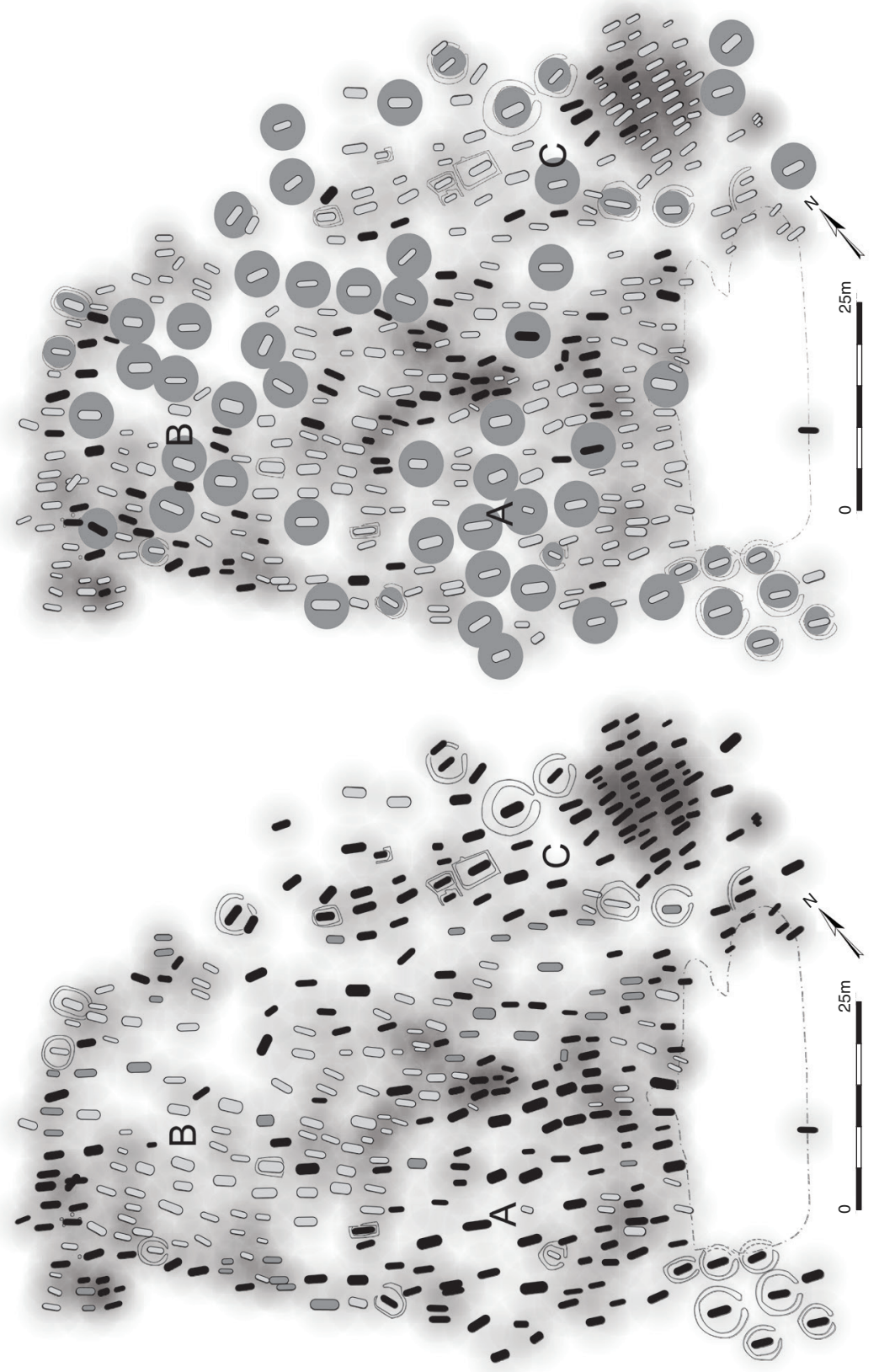

Figure 4.14 St Peters, Broadstairs, eastern Kent. Both plans show the clustering at $4 \mathrm{~m}$. On the left-hand plan the orientation of the graves is marked as black for $\mathrm{N}-\mathrm{W} / \mathrm{S}$-E, light grey for $\mathrm{E} / \mathrm{W}$, and dark grey are graves in-between the two. On the right-hand plan, small barrows have been marked where the graves had a $4 \mathrm{~m}$ gap and had satellite graves around them; in black are graves with integral features. 
Similarly to St Peters, the large cemetery at Finglesham deployed integral and external features to highlight a number of graves. Finglesham is located about eighteen miles $(29 \mathrm{~km})$ from Broadstairs, just south of the village after which it was named. This site was first identified during quarrying and was investigated in 1928 and 1929 when thirty-eight individuals were discovered; unfortunately part of the northern edge of the site had been lost. The remaining cemetery was excavated by Chadwick Hawkes between 1958 and 1967, taking the total up to 254 inhumations, ranging in date across the sixth and seventh centuries. The excavated cemetery is shaped like an irregular quadrilateral, with the eastern and southern edges having been identified (Chadwick, 1958; Chadwick Hawkes, 1977; 1981; 1982; Chadwick Hawkes et al., 1965; Chadwick Hawkes and Grainger, 2006; Sayer, 2009). Burials at Finglesham clustered at $4 \mathrm{~m}$ and were divided into four plots A, B, C and $\mathrm{D}$ (Figure 4.15). There were significant gaps between the four plots, and even at its narrowest the gap between $\mathrm{A}$ and $\mathrm{C}$ or D and $\mathrm{B}$ this was $4 \mathrm{~m}$.

A number of burials at Finglesham show evidence of having had medium-sized or small barrows over the top of them. During excavation the soils associated with grave 116 indicated the presence of a mound, and many graves sported ring ditches around their periphery (Chadwick Hawkes and Grainger, 2006). At Finglesham, like Orpington or St Peters, some of the sixth-century graves survived with a considerable gap left around them, with other burials that surrounded these spaces fossilising the shape of the now absent barrow. These satellite graves were located deliberately with respect to the barrow burial they encircled. Armed with this knowledge Grainger examined the space around each grave to explore the location of additional barrows. Regrettably, this investigation was never published, but these barrows were presented as part of Chadwick Hawkes' ongoing deliberations about the site (Chadwick Hawkes, 1982). As at St Peters, the Ripley's K-function analysis of Finglesham showed that graves clustered at $4 \mathrm{~m}$, dividing the site into four parts: a northern group, plot $\mathrm{A}$, and three predominantly seventh-century plots, plot $\mathrm{B}$ to the west, plot $\mathrm{C}$ to the east and plot $\mathrm{D}$ to the south. Many of the barrows that Grainger identified had been located within significant gaps in the cemetery plan; that is, $4 \mathrm{~m}$ away from other graves. Many of these barrow graves were also positioned with differing orientations to those adjacent. As at Orpington, these graves were placed like this deliberately to distinguish them, sharing their axes as part of a mnemonic strategy which employed a multi-layered visual connotation that created an association between them.

Finglesham also had integral features, and these were used in the same way as at St Peters (Figure 4.15). Plot A included just one grave with a posthole and this was a satellite burial around the northern 

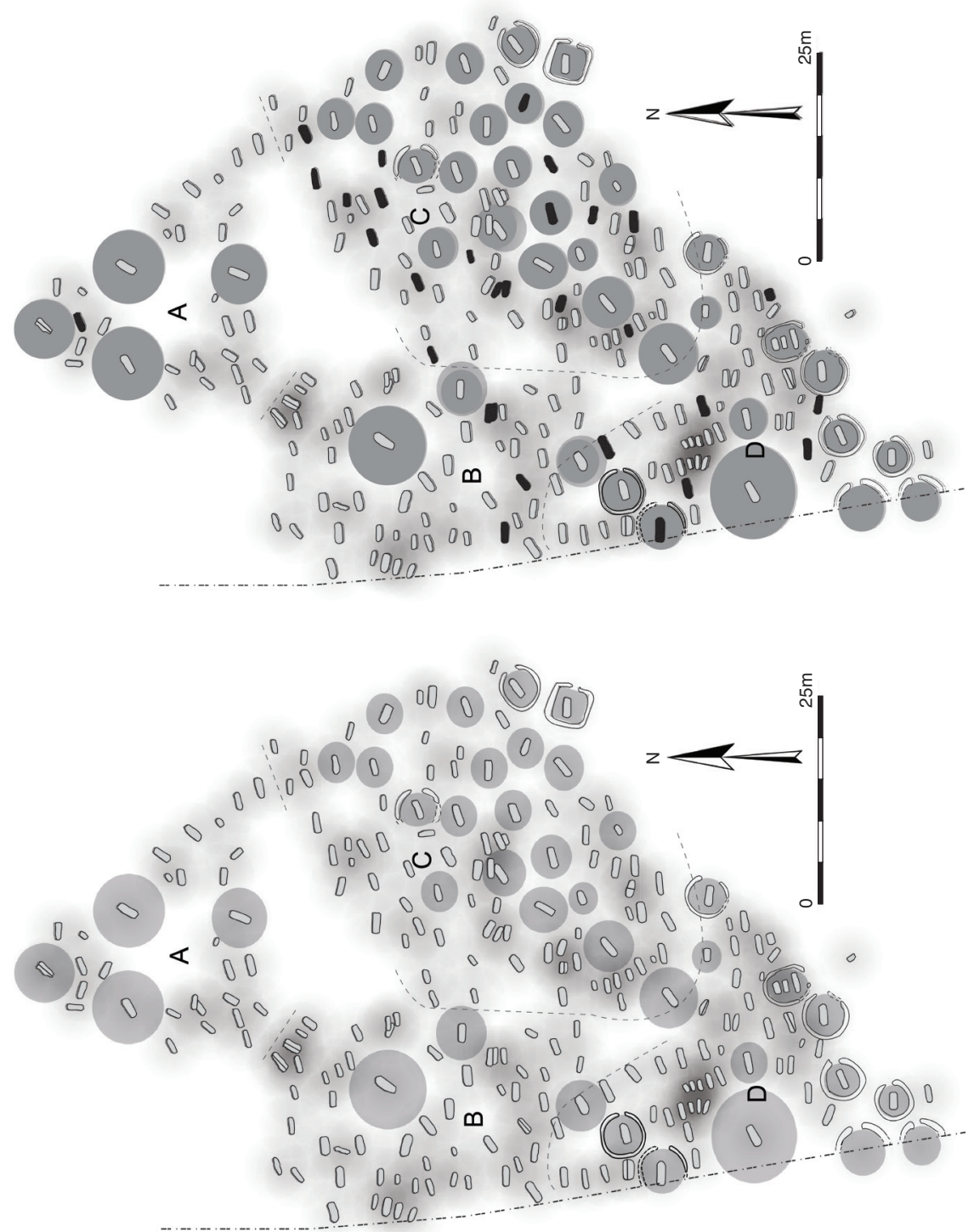

Figure 4.15 Finglesham, eastern Kent. Both plans show the clustering at $4 \mathrm{~m}$, and the left-hand plan shows how the clustering of graves defined four plots, A-D. On the right-hand plan, the location of barrows has been inferred where the graves had a $4 \mathrm{~m}$ gap and had satellite graves around them; in black are graves with integral features. 
barrow. Plots B and D included a greater quantity and variety of integral features, including five posthole graves, four ledge burials and two with sideboards. All eleven were found between barrow graves; just one grave, 93, included a posthole but it was located under a small barrow within a ring ditch. Most integral-feature graves were found in plot C, and almost all of these were in satellite burials. There were just two exceptions, graves 151 and 161, both the graves of adult women without gendered artefacts. Just as at St Peters, the graves with integral features were not often associated with central places, but surrounded them. In both cemeteries these graves were found in the highest-density parts of the cemetery. Ledges or sideboards supported structures or planks that were used to convey a specific message. In the majority of cases at both Finglesham and St Peters, integral grave structures and external structures, like barrows, were only rarely found on the same grave. As a result the two types of display must have been largely separate and so conveyed similar, but contrasting messages.

The dissimilarity of graves with different types of feature is also seen in how the graves were treated after burial. Alison Klevnäs (2013), identified an intensifying outbreak of deliberate grave robbery in sixthand seventh-century Kent. This activity targeted wealthy burials, and the robbers' intention was to destroy the artefacts, she argued, and thus obliterate the memory and the power of a grave. This behaviour was not aimed at personal enrichment, but at damaging the reputation and influence of surviving relatives. Grave robbing is seen outside Kent, in cemeteries like Barrington, Cambridgeshire; Spong Hill, Norfolk; Bloodmoor Hill, Suffolk; Apple Down, West Sussex; Winnall II, Hampshire; and Chadlington, Oxfordshire, among others. But in Kent it took place on a larger scale, involving fifteen known sites and over 200 graves; around 20 per cent of the graves may have been robbed. Klevnäs (2013: 83) suggested that this phenomenon was localised, the result of a feud and conflict between competing families. Ozengell, Bradstow School, Finglesham and St Peters were among the most heavily robbed cemeteries (see Table 4.5) and they also contained barrows or integral features (Figures 4.16 and 4.17).

Table 4.5 Targets of grave robbers: barrows and graves with integral features

\begin{tabular}{|c|c|c|c|c|c|}
\hline Cemetery & $\begin{array}{l}\text { Graves } \\
\text { investigated }\end{array}$ & $\begin{array}{l}\text { Number } \\
\text { robbed }\end{array}$ & $\begin{array}{l}\text { Proportion } \\
\text { robbed }\end{array}$ & $\begin{array}{l}\text { Barrows } \\
\text { robbed (total) }\end{array}$ & $\begin{array}{l}\text { Integral features } \\
\text { robbed (total) }\end{array}$ \\
\hline Bradstow School & 89 & 18 & $20 \%$ & $12(19)$ & $\mathrm{n} / \mathrm{a}$ \\
\hline Finglesham & 237 & 17 & $7 \%$ & $8(45)$ & $3(28)$ \\
\hline Ozengell & 89 & 39 & $44 \%$ & $\mathrm{n} / \mathrm{a}$ & $2(12)$ \\
\hline St Peters & 388 & 54 & $14 \%$ & $26(66)$ & $5(83)$ \\
\hline
\end{tabular}



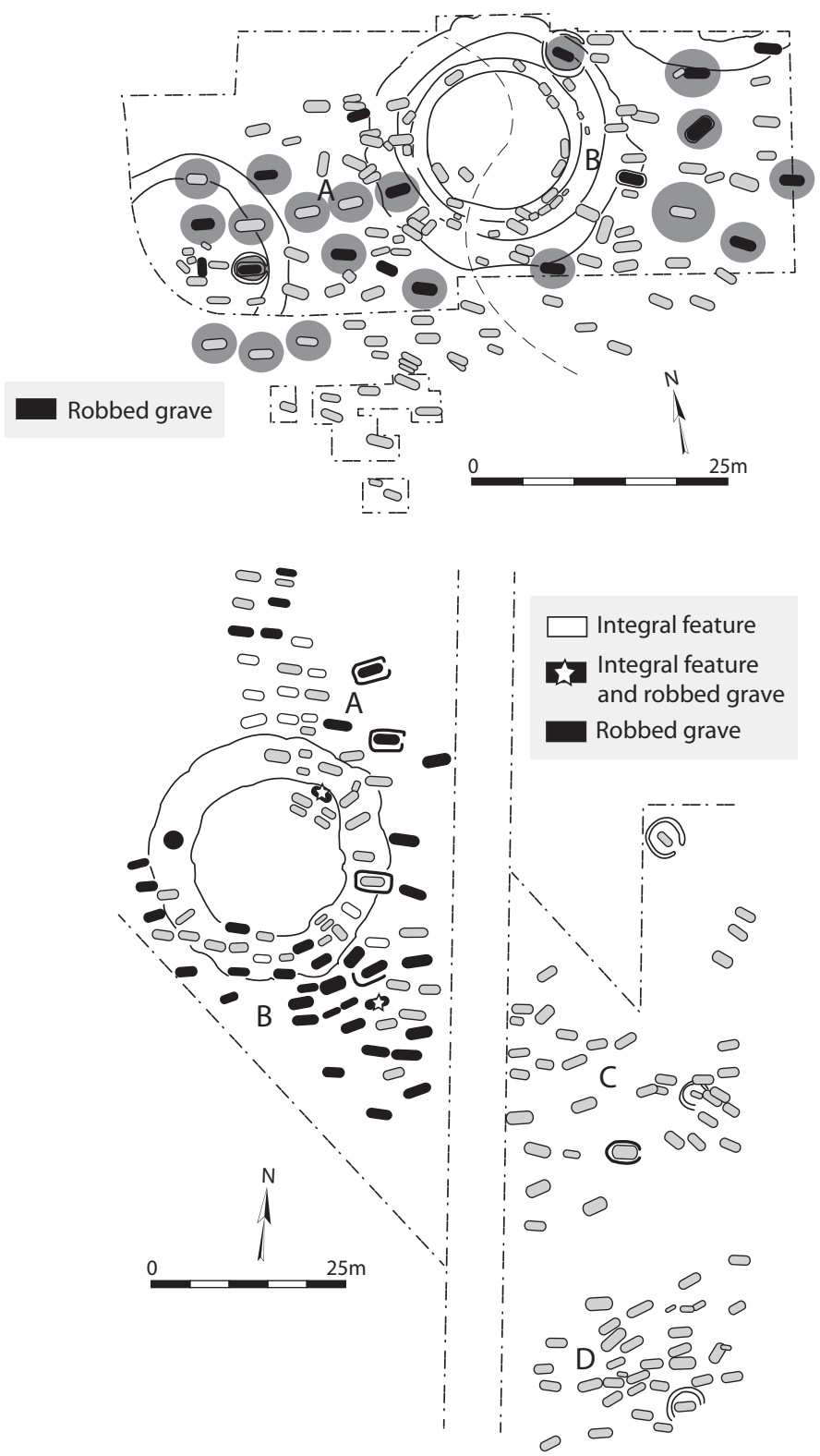

Figure 4.16 Bradstow School (top) and Ozengell (bottom), both in eastern Kent. Both cemeteries had been robbed in antiquity. At Bradstow School, the robbers targeted graves with visible barrows, whereas at Ozengell the robbers appear to have deliberately targeted particular graves: plot B was heavily robbed, but plot A was less heavily robbed and interestingly had more integral features. Just two graves with integral features were robbed. We do not know the extent of robbing in plots $\mathrm{C}$ and $\mathrm{D}$. 


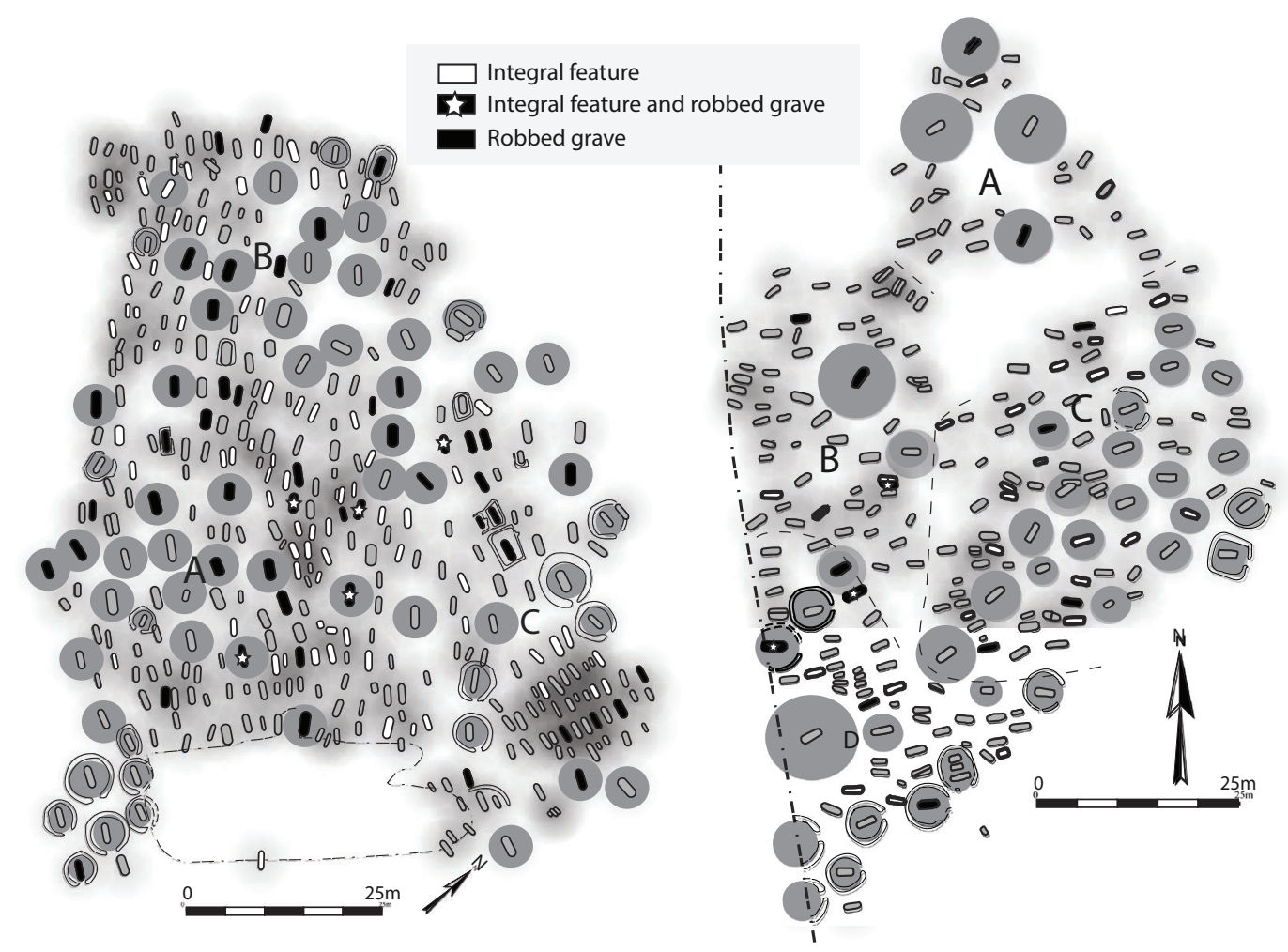

Figure 4.17 St Peters, Broadstairs, and Finglesham, both in eastern Kent. In these cemeteries, robbers were deliberately targeting individuals, particularly those under mounds. The same robbers also avoided graves with integral features. At St Peters, just five graves with integral features were robbed, and at Finglesham just three graves with integral features were robbed. 
In the cemeteries at Bradstow School, Finglesham and St Peters, it was possible to use spatial statistics, and the evidence of surrounding graves, to predict the location of additional barrows. The graves with barrows and other external features were more frequently robbed than burials with solely integral features. With forty-six robbed barrows and just ten graves with integral features ransacked, this contrast is striking and statistically significant. The calculation using Fisher's Exact Test $(p=(\mathrm{a}+\mathrm{b}) !(\mathrm{c}+\mathrm{d}) !(\mathrm{a}+\mathrm{c}) !(\mathrm{b}+\mathrm{d}) ! / \mathrm{n} ! \mathrm{a} ! \mathrm{b} ! \mathrm{c} ! \mathrm{d} 1)$ and the contingency table (Table 4.6) results in a $p$ value of less than 0.0001 . So the association between these variables is extremely statistically significant, indicating deliberate selection of barrows over graves with integral features.

Ozengell and Bradstow School are awkward inclusions because publications are still outstanding. It is not known whether they included barrows or integral features, though it is possible to do the same calculation for just Finglesham and St Peters. In that scenario (see Table 4.7) the $p$ value is also less than 0.0001 , indicating deliberate selection of barrows over graves with features.

In these east Kent cemeteries, grave robbers were deliberately targeting graves with external features like ditches or barrows. Interestingly, the association between robbing any grave and robbing one with integral features is also significant. The calculation using Fisher's exact test and the contingency table (Table 4.8) results in a $p$ value of 0.0210 . So the association between these variables is statistically significant, indicating the deliberate avoidance of graves with integral features by grave robbers.

Table 4.6 Grave robbers' preference: graves with integral features v. barrows at Bradstow School, Finglesham, Ozengell and St Peters

\begin{tabular}{llcc}
\hline & Robbed & Not robbed & Total \\
\hline barrow & 46 & 84 & 130 \\
integral feature & 10 & 113 & 123 \\
total & 56 & 197 & 253 \\
\hline
\end{tabular}

Table 4.7 Grave robbers' preference: graves with integral features v. barrows at Finglesham and St Peters

\begin{tabular}{lccc}
\hline & Robbed & Not robbed & Total \\
\hline barrow & 34 & 77 & 111 \\
integral feature & 8 & 103 & 111 \\
total & 42 & 180 & 222 \\
\hline
\end{tabular}


Table 4.8 Grave robbers' preference: flat graves v. graves with integral features

\begin{tabular}{llll}
\hline & Robbed & Not robbed & Total \\
\hline flat grave & 128 & 675 & 803 \\
integral feature & 10 & 113 & 123 \\
total & 138 & 788 & 926 \\
\hline
\end{tabular}

Table 4.9 Grave robbers' preference: flat graves v. graves with barrows

\begin{tabular}{lccc}
\hline & Robbed & Not robbed & Total \\
\hline barrow & 34 & 77 & 111 \\
flat grave & 128 & 675 & 803 \\
total & 162 & 752 & 914 \\
\hline
\end{tabular}

In a similar vein there was a deliberate selection of barrows over flat graves to rob (Table 4.9) with a $p$ value of less than 0.0001 , indicating that the grave robbers were deliberately selecting barrows over other graves to destroy.

Undeniably, raiders targeted rich graves, but they also purposely avoided those which had integral features. The only way someone could know that a burial had integral features is if they participated in the funeral, and so the grave robbers must have been active members of these communities. Graves with barrows and external features were selected because they had been identified as significant places. However, it is unlikely that robbers were aware of internal features in the same way and so the deliberate avoidance of these graves was the result of a related purpose. The robbers were not just selecting noticeable graves; they must have had semiotic knowledge of the cemetery and used this to maliciously target specific individuals - those ancestors important to specific parts of community identity.

The Ozengell cemetery is notable because graves with integral features were more often placed to the north of the site, and robbed graves were found to the south of a pre-existing ring ditch (Figure 4.16). At Finglesham and St Peters, these integral-feature burials were found around central graves, and focused on them, as discussed above (Figure 4.17). Ozengell is reminiscent of cemeteries divided into particular zones, with the northern plots subdivided into two areas, one identity group south of the barrow and one to the north, whereas at Finglesham and St Peters this second identity group was closely associated with certain individuals. In fact, at Finglesham only two of these satellite burials, grave 84 , with a pendant, and grave 170 , with a single small leaf-shaped spear (type C5; Swanton, 1974) displayed limited 
gender identity. In these Kentish cemeteries there were three distinct rituals within the cemetery:

1. burials with gendered objects or burial wealth in flat graves or barrows;

2. burials with integral features and objects, but rarely with gendered objects; and

3. burials in flat graves with limited or no gravegoods.

However, not all significant burials included objects, depending on chronological localised trends.

Elaborate funerals with marked graves recreated personhood for the deceased in the eyes of the funerary party and at the same time they reinforced old identities or contributed to the creation of new ones. Marked burials became central places within the cemetery, and their visible destruction was symbolic because it acted as a form of iconoclasm, disempowering the agency of that central place and shared ancestor. External features marked these central grave sites, but integral features were not often incorporated in them; moreover, graves that did have integral features must have been part of a limited funerary ritual carried out by a select group within the community. Perhaps these secondary rites recreated the personhood for the deceased or a select group, but in using integral features this group was not creating a central place. Integral features were perhaps more common among subgroups within the population, but importantly they had enough autonomy to have their own distinctive burial ritual.

\section{Semiotics and social differentiation in cemetery space}

One of the most useful analytical tools available to archaeologists is difference, and quite understandably gravegoods provide a useful vehicle to understand the differences that existed between graves. However, gravegoods are not the only difference present within mortuary archaeology. In Chapter 2 we discussed the semiotics of mortuary display, and the subsequent scales at which these tools operated. Body position, for example, is a characteristic of an individual burial, but we rarely find clusters of burials which shared body positions. Body position does not correspond with age, gender, status or time of death, any of which might suggest a wider cultural significance (see Pader, 1982; Faull, 1977 and Chadwick Hawkes, 1977; Mui, 2018). As a result, body position was probably meaningful to the mortuary party and those who laid out a corpse, but not necessarily to the extended narrative which outlived the funeral. Corresponding with that discordance, there are other leitmotifs 
within and between cemeteries - for example, personal characteristics like age and gender - that seem to have been an influence on where an individual was buried, depending on who that person was; the organisation of a cemetery was determined at a community level, and its layout provided a visual mnemonic used as an aid in the narrative description. This created mortuary semiotics which employed lasting devices, like external features, used to turn a cemetery into a scopic regime, a series of culturally constructed ways of seeing. Identities operated dissimilarly at different times. Finglesham and Orpington, for instance, included graves without any burial wealth whatsoever, but these same burials manifested significant agency because later graves, some furnished, were positioned at satellite locations around them. At both Finglesham and Orpington these significant graves were probably covered in small barrow mounds because they commanded some considerable visual authority.

The majority of cemeteries consisted of multiple groups of graves, either densely or loosely arranged into plots. In many graves the distribution of material culture varied between plots, and the density of graves was a way to distinguish between these groups, for example as at West Heslerton (see Chapter 2). Some grave plots included richer graves and this inclusion of visually signalled wealth made a statement about the individual, but also about the social group that constructed that plot. The inclusion of wealth in a grave was a socially coded statement, just like the erection of burial mounds, and seems to have been a significant part of how the plots were organised. Many cemeteries contained one plot which was wealthier than the others - for example, at Wakerley, Apple Down, West Heslerton, Great Chesterford or Holborough. Within many of these plots, wealthy graves were positioned in central zones among similar graves; alternatively they may have been dispersed, marking new focal points for each generation of new interments. However, the presence or absence of gravegoods is only part of the story and the location of graves was an important part of that display. Burial plots were not static entities, but themselves exhibited a number of different characteristics. In any given cemetery these characteristics could include a core of wealthy burials, or significant graves dispersed but identified as central points. Some sites had no core of wealthy graves at all - for example, Holborough.

Previous scholars have suggested that individual graves could be compared and ranked in hierarchal identity bands (Arnold, 1981; Steuer, 1968; Christlein, 1973; and Shephard, 1979). This is problematic, but the idea persists, at least in principle. Archaeologists regularly consider high-wealth burials as being of higher-status individuals (for examples, see Blacknall Field, in Annable and Eagles, 2010). However, gender, age and life course, as well as situational, political, regional and 
status identities, all played a role within the conglomerate, multi-layered mesh of identities that made up a persona. As a result, elements of an individual's identity intersected with artefact selection and spatial, technological and consumption practices during a single commemoration event. Equally, these identities were not internal or individualistic, but rather they resulted from membership of social and community groups and it is these groups who constructed burial events. Plots and satellite burials were mortuary technologies used to highlight group affiliation. Where cemeteries had multiple plots they highlighted nested group affiliations, sub-units within local identities. Core groups and barrow burials highlighted particular individuals within those mortuary populations, many from different generations. Burial plots consisted of many individuals with a mixture of ages, genders and identities, but there was also variation between plots within cemeteries.

As we saw at Leighton Buzzard III, Great Chesterford, Wakerley and Finglesham, there was hierarchy to group affiliation, and some plots had core burials creating mnemonic regimes for regional display, whereas others did not. These local community arrangements highlighted one primary group and one or two subsidiary groups, differentiated because they employed separate plots with less organisation and less focus on funerary narratives for retelling. These systems created a scopic regime for each site, and the messages embedded in these systems extended beyond the local site, creating a regional and pan-regional visual experience that defined each early Anglo-Saxon cemetery, and defined specific groups by their ancestral heritage. Sites like West Heslerton, Broadway Hill in Hereford and Worcester, Winterbourne Gunner near Salisbury, Lyminge II, Westgarth Gardens, Berinsfield, Deal, Bargates, Fonaby or Snell's Corner separated groups of gendered individuals into specific places, highlighting male or female characteristics in central places, and such arrangements may have been a way to define key lines of inheritance within dominant families. These recognisable structures drew on local and cultural tropes, and would have served to distinguish elite individuals and affiliate them with the living community who employed (and returned to) a cemetery for funerals and other social events. In some regions, particular cemeteries became central places for identity groups that existed within a broader community and encouraged the transportation of specific bodies, women and infants, to a specific burial place, probably because lingering associations and identities persisted after marriage, birth and death.

The inherent visual character of each grave cluster, and each cemetery, tells the story of a particular community and a particular social group. Wealthier plots seem to have included a greater depth of hierarchical expression: plots at Finglesham included multiple inhumation 
rites, barrows, integral features and furnished burials, and at Apple Down these rites included central burials, cremations or peripheral burials, with wealthy graves in a core at the centre of the cemetery. This was part of a cemetery's scopic regime and was used to identify significant community ancestors by their location and visual characteristics, which highlighted multiple aspects of community identities, those that its members felt were important. But with this signalling came a price, and the localised feuds between competing units extended to iconoclasm, leaving graves ransacked and objects broken, targeted because they had been important to how that community defined itself. This was particularly prevalent in Kent, and in Merovingian cemeteries, but it may have had a wider impact on funerary behaviour, affecting local decisions whether to bury the dead with objects, or under mounds, in earthen cemeteries, and eventually led to the decline of the furnished burial. 